\title{
Quantification of biologically and chemically bound phosphorus in activated sludge from full-scale plants with biological P-removal
}

Francesca Petriglieri ${ }^{a}$, Jette F. Petersen, ${ }^{a}$ Miriam Peces ${ }^{a}$, Marta Nierychlo ${ }^{a}$, Kamilla Hansen ${ }^{a}$, Cecilie E. Baastrand ${ }^{\mathrm{b}}$, Ulla Gro Nielsen ${ }^{\mathrm{b}}$, Kasper Reitzel ${ }^{\mathrm{c}}$, Per Halkjær Nielsen ${ }^{\mathrm{a} *}$.

${ }^{\mathrm{a} C e n t e r ~ f o r ~ M i c r o b i a l ~ C o m m u n i t i e s, ~ D e p a r t m e n t ~ o f ~ C h e m i s t r y ~ a n d ~ B i o s c i e n c e, ~ A a l b o r g ~ U n i v e r s i t y, ~}$ Aalborg, Denmark.

${ }^{b}$ Department of Physics, Chemistry and Pharmacy, University of Southern Denmark, Campusvej 55, DK-5230 Odense M, Denmark

${ }^{\mathrm{c}}$ Department of Biology, University of Southern Denmark, Campusvej 55, DK-5230 Odense M, Denmark

*Correspondence to: Per Halkjær Nielsen, Center for Microbial Communities, Department of Chemistry and Bioscience, Aalborg University, Fredrik Bajers Vej 7H, 9220 Aalborg, Denmark; Phone: +45 9940 8503; Fax: Not available; E-mail: phn@bio.aau.dk

\begin{abstract}
Large amounts of phosphorus (P) are present in activated sludge from municipal wastewater treatment plants, where it exists in the form of metal salt precipitates or biologically bound into the biomass as nucleic acids, cell membrane components, and the extracellular polymeric substances or, in special polyphosphate-accumulating organisms (PAOs), as intracellular polyphosphate. Only recently, methods that reliably allow an absolute quantification of the different $\mathrm{P}$-fractions, such as sequential extraction, Raman microspectroscopy, solid-state ${ }^{31} \mathrm{P}$ magic angle spinning (MAS) NMR, and solution state ${ }^{31} \mathrm{P}$ NMR have been developed. This study combines these techniques to obtain a comprehensive $\mathrm{P}$ mass-balance of activated sludge from four wastewater treatment plants with enhanced biological phosphate removal (EBPR). The total content of $\mathrm{P}$ and various cations was measured by chemical analysis (ICP-OES), and different $\mathrm{P}$ fractions were extracted for chemical characterization. Chemically bound P constituted 38-69\% of total P, most likely in the form of $\mathrm{Fe}, \mathrm{Mg}$, or $\mathrm{Al}$ minerals, while organically bound $\mathrm{P}$ constituted 7-9\%. By using Raman microspectroscopy and solution state ${ }^{31} \mathrm{P}$ NMR and ${ }^{31} \mathrm{P}$ MAS NMR spectroscopy before and after anaerobic P-release experiments, poly-P was quantified and constituted 22-54\% of total $\mathrm{P}$ in the activated sludges and was found in approx. $25 \%$ of all bacterial cells. Moreover, Raman microspectroscopy in combination with fluorescence in situ hybridization (FISH) was used to quantify the species-specific intracellular poly-P of known PAO genera (Tetrasphaera, Ca. Accumulibacter, Dechloromonas) and other microorganisms known to possess high level of poly-P, such as the filamentous $\mathrm{Ca}$. Microthrix. They were all abundant, as measured by quantitative-FISH and amplicon sequencing, and accumulated large amount of poly-P, depending on their cell-size, contributing substantially to the P-removal. Interestingly, in all four EBPR plants investigated, only $1-13 \%$ of total poly-P was stored by unidentified PAO, highlighting that most PAOs in the fullscale EBPR plants investigated are now known.
\end{abstract}




\section{Highlights}

- Exhaustive P mass-balance of main organic and inorganic P-species in four EBPR plants

- Quantification of poly-P of FISH-defined PAO and other species with high P content

- Total P content was $36-50 \mathrm{mgP} / \mathrm{gSS}$ of which $31-62 \%$ was in biomass and as poly-P

- A high fraction of all cells (25-30\%) contained a high content of poly-P

- Known PAOs contained almost all poly-P in the EBPR plants investigated

\section{Introduction}

Phosphorus (P) is a vital nutrient for all living organisms, but its cycle has been largely altered by human activities, resulting in increasing concerns about its supplies (Liu et al., 2016). Moreover, an uncontrolled $\mathrm{P}$ discharge into water bodies may cause eutrophication, which is harmful to animals and humans, but this can be partially prevented with efficient removal of $\mathrm{P}$ from wastewater (Oehmen et al., 2007). Nowadays, this is often achieved by introduction of the enhanced biological phosphorus removal (EBPR) process, without the need for chemical precipitants (Nielsen et al., 2019). It offers a sustainable method to recover $P$, where surplus activated sludge can be added to digesters and produce an effluent with a high concentration of soluble $\mathrm{P}$ well suited for subsequent P-recovery, e.g., as struvite, that can be used as fertilizer (Ek et al., 2006). High concentration of $P$ is not unusual in wastewater, and in several studies it has been reported within the range of 5-15 mgP/L (Adam et al., 2009; Mino et al., 1984; Shiba and Ntuli, 2017; Wilfert et al., 2015). Worldwide, around 1.3 Mt P are treated every year in municipal wastewater treatment plants (WWTPs), which therefore represent an important source for P recovery and may theoretically substitute 40-50\% of phosphate fertilizer applied in agriculture (Egle et al., 2016; Vuuren et al., 2010). Together with the EBPR process, chemical phosphorus removal (CPR) using iron or aluminum salts is the most widely applied method to remove $\mathrm{P}$ from wastewater. Iron salts, in particular, are extensively used because of their lower price and efficiency for P precipitation, odour control, and corrosion control (Wilfert et al., 2015, 2016).

Activated sludge typically contains 5-15 mgP/gSS for non-EBPR sludge and 30-50 mg P/gSS for EBPR sludge (Jensen et al., 2015; Menar and Jenkins, 1970; Metcalf \& Eddy Inc. et al., 2014), but the $\mathrm{P}$ content can vary substantially among different treatment plants, comprising in general two main fractions: chemically- and biologically-bound (biogenic) P (Mino et al., 1984). In most of the cases, large amount of $\mathrm{P}$ is present as inorganic $\mathrm{P}$, in the form of insoluble metal salts of calcium, iron, or aluminum, naturally present in the sludge, sometimes in large amounts, e.g., as vivianite (Mino et al., 1984; Wilfert et al., 2016). This fraction has been estimated in different studies and can vary from $55 \%$ to $85 \%$ of the total P (González et al., 2005; Xie et al., 2011). 
Although inorganic P may be predominant in some activated sludge systems, biogenic $\mathrm{P}$ also plays a key role in the biomass. It is present in DNA and other nucleic acids, in cell membranes, in the extracellular polymeric substances (EPS), or in the form of orthophosphate, pyrophosphate, and polyphosphate (poly-P), normally accounting for 6.6-10.5\% of total P (Mino et al., 1984; Zhang et al., 2013a). In particular, in EBPR sludge, a large fraction of biogenic $\mathrm{P}$ is constituted by poly-P, an intracellular storage compound typical of polyphosphate-accumulating organisms (PAO) (Nielsen et al., 2019; Oehmen et al., 2007). The EBPR process specifically selects for these microorganisms by alternating anaerobic feast and aerobic famine conditions. In the anaerobic phase, PAO take up carbon sources (e.g., acetate) and store them intracellularly as polyhydroxyalkanoates (PHA) using poly-P and, if present, glycogen hydrolysis as a source of energy. In the following aerobic phase, the stored PHA is degraded to supply growth and poly-P replenishment (Oehmen et al., 2007). Only recently, with the development of new methods, the poly-P fraction in some EBPR sludges have been quantified and reported to span between 20 and $60 \%$ of total P (Boisen et al., 2019; Fernando et al., 2019).

Activated sludge in the EBPR process comprises thousands of bacterial species, but only few genera have been recognized as PAOs. Among these are members of the genera $\mathrm{Ca}$. Accumulibacter and Tetrasphaera (Nielsen et al., 2019) the most known. Both genera are common and abundant in EBPR plants worldwide (Nielsen et al., 2019), and their dynamics of storage polymers and significant contribution to $\mathrm{P}$ removal have been demonstrated in situ in several Danish WWTPs (Fernando et al., 2019). More recently, the physiology of novel PAO from the genus Dechloromonas has been investigated in situ by Raman microspectroscopy, showing a similar metabolism to $\mathrm{Ca}$. Accumulibacter, and their potential contribution to the EBPR process (Petriglieri et al., 2020). Several putative PAOs, such as Tessaracoccus and Ca. Obscuribacter are often found in lower abundance in WWTPs (Stokholm-Bjerregaard et al., 2017), but their importance remains undescribed (Nielsen et al., 2019). Besides typical PAOs, which are cycling P in aerobic/anaerobic conditions, other microorganisms, such as $\mathrm{Ca}$. Microthrix are known to store poly-P and release it with slower dynamics (Nielsen et al., 2002; Wang et al., 2014b, 2014a). Even though $\mathrm{P}$ is not cycled in these organisms as in typical PAOs, they may still contribute substantially to P removal in EBPR plants (Blackall et al., 1996; Wang et al., 2014a, 2014b). Therefore, the identification of novel PAOs and the optimization of their P uptake and release in EBPR systems is of utmost interest for process development and streamlining.

$\mathrm{P}$ recovery strategies rely on the specific types of $\mathrm{P}$ actually present in activated sludge. A range of methods exist to characterize all $\mathrm{P}$ fractions, such as inductively coupled plasma optical emission spectrometry (ICP-OES). Recently, a new method has been developed by Staal et al. (2019) for the characterization of different $\mathrm{P}$ pools in activated sludge, applying sequential $\mathrm{P}$ fractionations, which classifies $\mathrm{P}$ compounds by their chemical reactivity in specific inorganic P-pools, such as Fe-P or Ca-P (Reitzel, 2005; Staal et al., 2019). The subsequent application of solution ${ }^{31} \mathrm{P}$ nuclear magnetic resonance (NMR) spectroscopy, used to identify and estimate $\mathrm{P}$ compounds based on the chemical bond type, can then provide information on organic $\mathrm{P}$ forms as well as condensed inorganic 
phosphates (pyro-P and poly-P) (Hupfer et al., 2008; Staal et al., 2019) in the sample. In contrast, common methods used for detection and quantification of intracellular poly-P in environmental samples are not completely reliable, as they suffer from several limitations such as inefficient extraction or degradation of poly-P (Majed et al., 2012). One of the most used techniques is staining with DNA-binding dyes followed by fluorometry, which may be unsuccessful because of the failure of the dye to penetrate cell membranes or the degradation of storage compounds during alkaline extraction (Staal et al., 2019). Raman microspectroscopy in combination with fluorescence in situ hybridization (FISH) provides a reliable single-cell level identification and quantification of intracellular poly-P in activated sludge (Majed et al., 2012), and it was recently used to successfully quantify poly-P content and other storage compounds in PAO cells in situ (Fernando et al., 2019; Petriglieri et al., 2020). The combination of Raman microspectroscopy with solid-state ${ }^{31} \mathrm{P}$ magic angle spinning (MAS) NMR and solution state ${ }^{31} \mathrm{P}$ NMR will therefore allow a reliable identification and quantification of total poly-P in environmental samples, including intracellular poly-P in activated sludge.

In this study, we combined a range of independent techniques to establish a robust and comprehensive $\mathrm{P}$ mass-balance covering all main inorganic chemical and biogenic $\mathrm{P}$-species in activated sludge from four full-scale EBPR plants, which were selected based on their large size and long and stable operation. Total $\mathrm{P}$ was determined in activated sludge by chemical analysis (ICPOES) and the inorganic $\mathrm{P}$ pools were characterized by $\mathrm{P}$ fractionation. The biomass was quantified by fluorescence microscopy, obtaining important information on average cell number and size, and total intracellular poly-P in the microbial biomass was estimated by Raman microspectroscopy, whereas poly-P in the bulk sludge sample was identified by solid-state ${ }^{31} \mathrm{P}$ MAS NMR, and solution state ${ }^{31} \mathrm{P}$ NMR. The contribution of individual PAO genera to $\mathrm{P}$ removal was determined by measuring the levels of intracellular poly-P in FISH probe-defined PAO cells.

\section{Materials and Methods}

\section{Description of the WWTPs involved}

Four full-scale EBPR WWTPs (Aalborg West, Ejby-Mølle, Lynetten, Viby) were investigated and details about their design, operation, and performance are given in Table S1. Briefly, the four plants had an alternating/recirculating design, with size between 100,000 and 1,000,000 population equivalents (PE). Two plants (Aalborg West and Lynetten) had return sludge side-stream hydrolysis ( $\mathrm{SSH})$. The yearly temperature range was $7-20^{\circ} \mathrm{C}$. The sludge residence time in the anaerobic tanks was 2-3 $\mathrm{h}$ for mainstream plants and $24-28 \mathrm{~h}$ for the SSH plants. All plants received occasional iron dosages for improving precipitation of phosphorus and enhancing flocculation. Viby had in a period before the investigation increased Fe-dosage. All plants had good and steady operation for long time, with effluent concentrations of total $\mathrm{P}$ of $0.1-0.5 \mathrm{mg} \mathrm{P} \mathrm{L}{ }^{-1}$, and always below the limit of 1.0 mg $\mathrm{P} \mathrm{L}^{-1}$. Activated sludge samples were collected from the aeration tank (at the end of aeration phase for plants with alternating operation), and transported on ice to the laboratory within few hours. Total suspended solids (TSS) was measured in accordance with Standard Methods (APHA et 
al., 2005). Volatile suspended solids (VSS) information was provided by the plants. An overview of the study design and all the methods applied is shown in Figure 1.

\section{Sequential P fractionation}

The modified Psenner fractionation was carried out as previously described by Reitzel (2005), with a fractionation scheme that includes P associated with humic acids (Reitzel, 2005). Centrifuged activated sludge ( $1 \mathrm{~g}$ wet-weight) was used for fractionation and the scheme consisted of six sequential extraction steps: $\mathrm{H}_{2} \mathrm{O}, 0.11 \mathrm{M}$ bicarbonate-dithionite (BD), $0.1 \mathrm{M} \mathrm{NaOH}$ and $0.5 \mathrm{M} \mathrm{HCl}$, filtration and combustion of the $\mathrm{NaOH}$ fraction to obtain Humic-P, and a final combustion step to obtain the residual P (Res-P) as summarized in Table S2. This scheme, originally developed for lake sediments, has been previously used for investigation of $\mathrm{P}$ pools in activated sludge (Roske and Schonborn, 1994; Uhlmann et al., 1990). P was analyzed (as molybdate reactive P) in the 6 extracts (referred to as $\mathrm{H}_{2} \mathrm{O}-\mathrm{P}$, BD-P, NaOH-P, HCl-P, Humic-P, and Residual-P) as described above, and total $\mathrm{P}$ in the extracts (TP) was measured after conversion of all $\mathrm{P}$ in the sample to ortho-P by wet oxidation $\left(5 \mathrm{~mL}\right.$ of the fraction mixed with $1 \mathrm{~mL}$ potassium peroxodisulfate $\left(\mathrm{K}_{2} \mathrm{~S}_{2} \mathrm{O}_{8}, 0.2 \mathrm{M}\right.$ solution) at $120^{\circ} \mathrm{C}$ for $1 \mathrm{~h}$ ). The difference between TP and ortho-P was called non-reactive $\mathrm{P}(\mathrm{nrP})$. The $\mathrm{P}$ fractions were normalized to the measured TP of the sludge sample, since these were associated with fewer handling steps and potential errors.

\section{Phosphorus release experiments from activated sludge}

Batch experiments were conducted in triplicates on fresh activated sludge to analyse total $\mathrm{P}$ and poly-P-content per cell of FISH-defined cells under anaerobic and aerobic conditions. Fresh activated sludge samples (approx. $4 \mathrm{gSS} / \mathrm{L}$ ) were aerated for $30 \mathrm{~min}$ to exhaust most intracellular carbon reserves and the biomass was used to measure poly-P-full cells. After aeration, sludge was transferred to $200 \mathrm{ml}$ serum bottles and sealed with rubber stopper and aluminium cap. Pure nitrogen was used to flush the headspace in each bottle to ensure anaerobic conditions. A carbon source containing a mixture of acetate, glucose, and casamino acids was added to provide substrates for as many species of PAO as possible, with a final concentration of the three components of 500, 250 , and $250 \mathrm{mg} / \mathrm{L}$, respectively. The serum bottles were kept at room temperature $\left(\sim 22^{\circ} \mathrm{C}\right)$ with shaking for $3 \square \mathrm{h}$. Samples for ortho-P analysis were collected every $20 \mathrm{~min}$ for the first hour of the experiment, and every 30 min during the remaining 2 hours. Biomass from the beginning $(0 \mathrm{~h})$ and the end of the anaerobic phase $(3 \mathrm{~h})$ were used to quantify poly-P and other $\mathrm{P}$ fractions in the sludge by solution NMR (see below). Additionally, samples from the beginning $(0 \mathrm{~h})$ and the end of the experiment $(3 \mathrm{~h})$ were flash-frozen in liquid nitrogen and subsequently freeze-dried for ${ }^{31} \mathrm{P}$ MAS NMR or fixed for FISH and Raman analyses (see below).

\section{Chemical analyses}

The ortho-P released into the liquid phase was analysed in accordance with ISO 6878:2004 using the ammonium molybdate-based colorimetric method. Total $\mathrm{P}, \mathrm{Fe}, \mathrm{Al}, \mathrm{Ca}, \mathrm{Mg}, \mathrm{K}$, and $\mathrm{Na}$ were measured in the fresh activated sludge samples. Sludge was homogenized for $10 \mathrm{sec}$. with a tissue homogenizer (Heidolph, Schwabach, Germany) and stored at $-20^{\circ} \mathrm{C}$ until further analysis. Nitric acid $(67 \%)$ was used to dissolve $0.5 \mathrm{~mL}$ of each sludge sample and the samples were microwave 
heated, according to (U.S. EPA 2007). The total amount of $P$ and other elements in the samples were analysed in triplicates by ICP-OES, according to Jørgensen et al. (2017).

\section{Poly-P quantification by solution state ${ }^{31}$ P NMR spectroscopy}

To identify and quantify poly-P in the sludge, solid state (see below) and solution state ${ }^{31} \mathrm{P}$ NMR spectroscopy was carried out as recently described in Staal et al. (2019). Briefly, $30 \mathrm{~mL}$ of activated sludge were centrifuged for $10 \mathrm{~min}$ at $2000 \mathrm{rpm}$ and the sludge pellet was used for a two-step extraction, with a $1 \mathrm{~h}$ pre-extraction in $40 \mathrm{~mL}$ of a $0.05 \mathrm{M}$ EDTA solution followed by a main extraction in $40 \mathrm{~mL}$ of $0.25 \mathrm{M} \mathrm{NaOH}$ for $16 \mathrm{~h}$. Quantitative ${ }^{31} \mathrm{P}$ solution NMR spectra were recorded on a JEOL ECZ 500R $500 \mathrm{MHz}$ spectrometer, using a $90^{\circ}$ pulse (12 $\left.\mu \mathrm{s}\right), 2.16 \mathrm{~s}$ acquisition time, 25 s relaxation delay, 512 scans, and proton decoupling. Spectra were processed with the MestReNova software using a $5 \mathrm{~Hz}$ line broadening with an exponential window function and with zero-filling to $64 \mathrm{~K}$ points ( $32 \mathrm{~K}$ points were recorded).

\section{Poly-P quantification by solid-state ${ }^{31}$ P MAS NMR spectroscopy}

Quantitative solid-state ${ }^{31} \mathrm{P}$ MAS NMR spectra were recorded on a $500 \mathrm{MHz}(11.7 \mathrm{~T}) \mathrm{NMR}$ spectrometer with a JEOL resonance ECZ 500R console and $11.7 \mathrm{~T}$ Oxford magnet using $3.2 \mathrm{~mm}$ triple resonance MAS NMR probe, single pulse excitation ( $45^{\circ}$ pulse), 2-3 min relaxation delay (optimized on sample), 150 scans, and $15 \mathrm{kHz}$ spinning. A synthetic sample of struvite, $\mathrm{NH}_{4} \mathrm{MgPO}_{4} \cdot 6 \mathrm{H}_{2} \mathrm{O}$, was used for quantitative determination of the diamagnetic $\mathrm{P}$ content in the samples and $85 \%$ phosphoric acid was used as a chemical shift reference $\left(\delta_{\text {iso }}\left({ }^{31} \mathrm{P}\right)=0 \mathrm{ppm}\right)$. VnmrJ and MestrNova were used for data analyses. A detailed description of the protocol for data analyses was recently reported (Staal et al., 2019).

\section{Biomass fixation}

Fresh biomass samples from batch reactors and full-scale activated sludge WWTP were either stored at $-80^{\circ} \mathrm{C}$ for sequencing workflows or fixed for FISH with $96 \%$ ethanol or $4 \%$ PFA (final concentration), as previously described (Nielsen, 2009) and stored at $-20^{\circ} \mathrm{C}$ until analyses.

\section{Cell counting and size measurement}

Total number of bacterial cells, calculated in triplicates, was determined using an Axioskop epifluorescence microscope (Carl Zeiss, Oberkochen, Germany) after staining for 30 min with 50 $\mu \mathrm{g} / \mathrm{mL}$ DAPI (4,6-diamino-2-phenylindoldihydrochlorid-dilactate). Areas of 1,500 cells for Raman microspectroscopy analysis (see below) was measured using ImageJ (Schneider et al., 2012). The biovolume of the cells was estimated by categorizing cells into perfect geometric shapes. The biovolume of filamentous bacteria was calculated considering filaments as perfect cylinders assuming an average cell length of $1 \mu \mathrm{m}$. Since rod-shape cells could not be classified as perfect cylinders or perfect spheroids, the biovolume of rod-shaped cells was calculated following Lee and Fuhrman et al. (1987) and Frølund et al. (1996) methodology. Briefly, the biovolume of rod-shape cells was estimated averaging the volume calculated considering rods as perfect cylinders with halfsphere ends and the volume calculated considering rods as perfect spheroids. The average width of 
filaments and rod-shaped cells was obtained by 2D image analysis using ImageJ (Schneider et al., 2012) for 1,000 cells, respectively.

\section{S rRNA gene amplicon sequencing}

Composition of the microbial community was quantified using FISH and amplicon sequencing. DNA extraction of activated sludge samples from the MiDAS collection (McIlroy et al., 2017) was performed as described by Stokholm-Bjerregaard et al. (2017). Briefly, DNA was extracted using the FastDNA spin kit for soil (MP Biomedicals), following the manufacturer's indications, but with an increase of the bead beating to $6 \mathrm{~m} / \mathrm{s}$ for $4 \times 40 \mathrm{~s}$, using a FastPrep FP120 (MP Biomedicals). Full-length 16S rRNA gene sequencing, preparation, and taxonomic assignment of full-length 16S rRNA gene amplicon sequence variants (FL-ASVs), and amplicon sequence variant analysis (ASV) were performed as described elsewhere (Dueholm et al., 2020). Data was analyzed using R (version 3.5.2) and RStudio software (R Development Core Team, 2008).

\section{Fluorescence in situ hybridization and quantitative FISH}

FISH was performed as described by Daims et al. (2005) using a set of specific probes: PAO651 (Crocetti et al., 2000) targeting Ca. Accumulibacter, MCX840 (Nierychlo et al., unpublished) targeting the genus $\mathrm{Ca}$. Microthrix, Bet135 (Kong et al., 2007), and Dech443 (McIlroy et al., 2016) targeting the most abundant species of Dechloromonas, and Actino658 (Kong et al., 2005), Tetra183, and Tetra617 (Dueholm et al., 2019) to target the genus Tetrasphaera. Details about the optimal formamide concentration and use of competitors or helper probes can be found in Table S3. Quantitative FISH (qFISH) biovolume fractions of individual taxa were calculated as a percentage area of the total biovolume, hybridizing the EUBmix probes (Amann et al., 1990; Daims et al., 1999), that also hybridizes with the specific probe. Microscopic analysis was performed with a white light laser confocal microscope (Leica TCS SP8 X). qFISH analyses were based on 30 fields of view taken at 630× magnification using the Daime image analysis software (Daims et al., 2006).

\section{Raman microspectroscopy}

Raman microspectroscopy was applied in combination with FISH as previously described by Fernando et al., (2019) to measure intracellular content of poly-P and other storage polymers in the cells from the beginning $(0 \mathrm{~h})$ and the end $(3 \mathrm{~h})$ of anaerobic P-release experiments. Briefly, FISH was conducted on optically polished $\mathrm{CaF}_{2}$ Raman windows (Crystran, UK), which give a singlesharp Raman marker at $321 \mathrm{~cm}^{-1}$ that serves as an internal reference point in every spectrum. Specific FISH probes (labelled with Cy3 dye) (Table S3) were used to locate the target cells for Raman analysis. After bleaching, spectra from single-cells were obtained using a Horiba LabRam HR 800 Evolution (Jobin Yvon, France) equipped with a Torus MPC 3000 (UK) 532 nm $341 \mathrm{~mW}$ solid-state semiconductor laser. The Raman spectrometer was calibrated prior to obtaining all measurements to the first-order Raman signal of silicon, occurring at $520.7 \mathrm{~cm}^{-1}$. The incident laser power density on the sample was attenuated down to $2.1 \mathrm{~mW} / \mu \mathrm{m}^{2}$ using a set of neutral density (ND) filters. The Raman system was equipped with an in-built Olympus (model BX-41) fluorescence microscope. A 50X magnification, 0.75 numerical aperture dry objective (Olympus M Plan Achromat- Japan), with a working distance of $0.38 \mathrm{~mm}$, was used throughout the work. A 
diffraction grating of $600 \mathrm{~mm} /$ groove was used, and the Raman spectra collected spanned the wavenumber region of $200 \mathrm{~cm}^{-1}$ to $1800 \mathrm{~cm}^{-1}$. The slit width of the Raman spectrometer and the confocal pinhole diameter were set respectively to $100 \mu \mathrm{m}$ and $72 \mu \mathrm{m}$. Raman spectrometer operation and subsequent processing of spectra were conducted using LabSpec version 6.4 software (Horiba Scientific, France). All spectra were baseline corrected using a $6^{\text {th }}$ order polynomial fit.

\section{Determination of total poly-P and other storage polymers in all bacteria and in PAOs}

The determination of the amount of intracellular poly-P and other storage polymers was carried out as described by Fernando et al. (2019). The method assumes that the intensity of the Raman signal is directly dependent on the amount of the analyte in a determined area. Using the same settings as applied in the cited paper and knowing the area of the analysed cells, it was possible to calculate the amount of poly-P and other storage polymers in chosen cells. The same principle has been applied in this study to calculate the intracellular poly-P content of the total biomass. It was measured by Raman microspectroscopy as an average of 1,500 cells randomly selected during the analysis in samples collected from the aeration tanks at the end of the aerobic phase $(0 \mathrm{~h})$ and after lab-scale release during anaerobic conditions $(3 \mathrm{~h}$ ) (see Supplementary text 1 ). An average amount of poly-P per cell was calculated as a factor of a constant determined during calibration for poly-P (Fernando et al., 2019), the average charge-coupled device (CCD) counts determined during the experiment, and the average area of cells measured by image analysis (see "Cell counting and size measuring"). This average value of poly-P per cell was multiplied by the total number of bacterial cells, counted after DAPI staining (see "Cell counting and size measuring"). As some filamentous bacteria are known to possess inclusions of storage polymers including poly-P (Nielsen et al., 2002; Wang et al., $2014 b$ ), they were included in the analysis. As it for many filaments is very difficult to determine the area of single cells inside filaments with common microscopic techniques, an arbitrary area was determined by multiplying the width of each filament measured with image analysis by $1 \mu \mathrm{m}$, obtaining in this way the amount of poly-P in an average segment of $1 \mu \mathrm{m}$ length. Distribution analysis of the poly-P content and cell size was performed using R (version 3.5.2) (R Development Core Team, 2008) and RStudio software.

\section{Results and Discussion}

The overall approach and overview of the study design is shown in Figure 1. We applied several independent methods to establish a comprehensive and robust mass balance of activated sludge from 4 full-scale EBPR plants covering P-species both chemically- and biologically-bound. These general techniques showed a high content of $\mathrm{P}$ (36-50 $\mathrm{mgP} / \mathrm{gSS})$, of which a substantial fraction (31-62\%) was part of the biomass in the form of organic $\mathrm{P}$ and poly-P. The individual contribution of the known PAO to $\mathrm{P}$ removal indicated that most of the important PAOs in the plants investigated were described. 


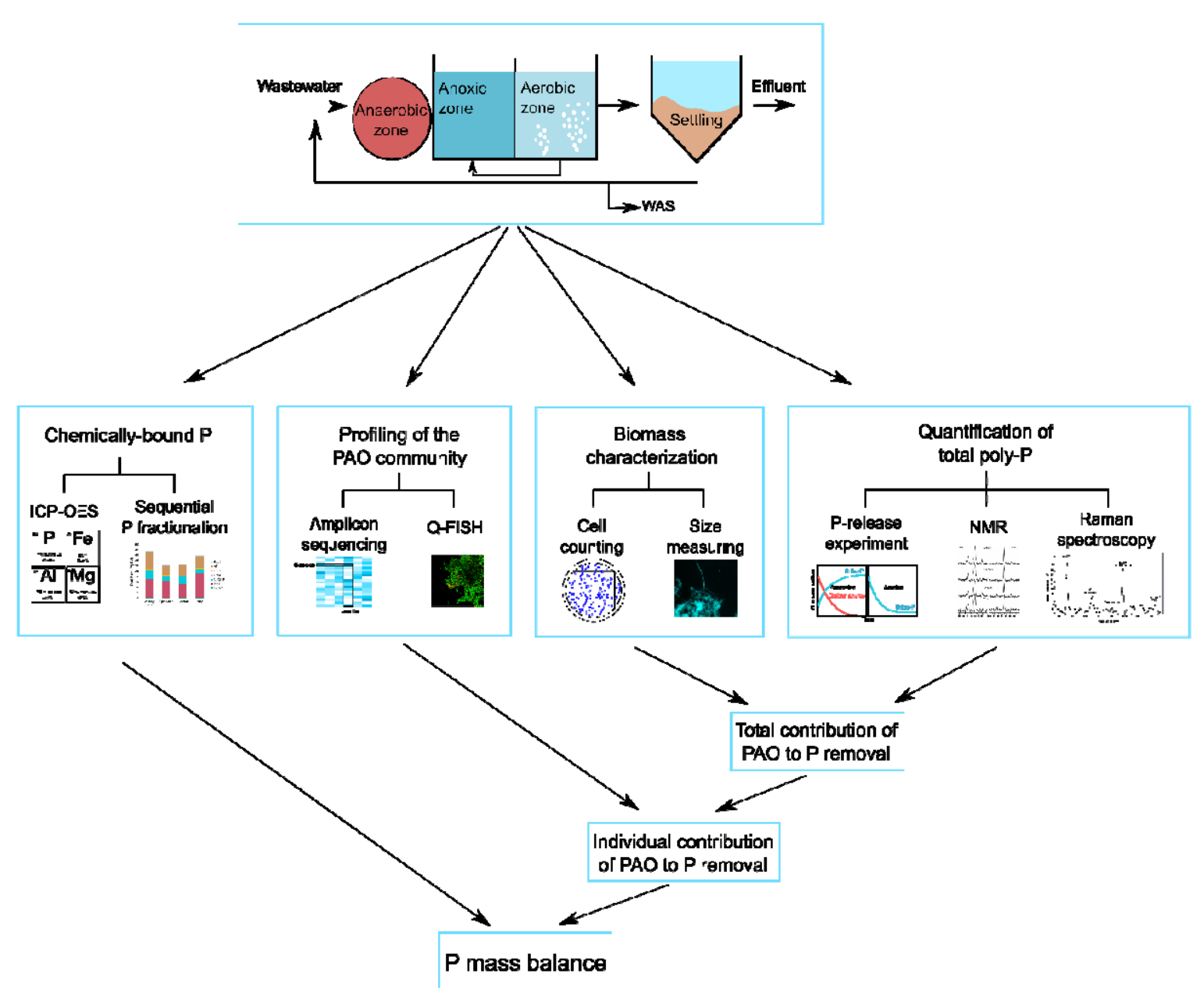

Figure 1. Overview of the study design. WAS = waste activated sludge; ICP-OES = inductively coupled plasma optical emission spectrometry ; $\mathrm{PAO}=$ polyphosphate-accumulating organisms; $\mathrm{Q}-\mathrm{FISH}=$ quantitative fluorescence in situ hybridization; poly-P = polyphosphate; $\mathrm{NMR}=$ nuclear magnetic resonance.

\section{Overall chemical composition of the four activated sludge}

The main inorganic element besides $\mathrm{P}$ of the four activated sludge samples were $\mathrm{Ca}, \mathrm{Na}, \mathrm{Fe}$, and $\mathrm{K}$ (Table 1). Mg, Al, and $\mathrm{Mn}$ were also present in lower amounts. All these elements are normally present in wastewater and may form insoluble salts with $\mathrm{P}$, in particular $\mathrm{Fe}^{3+}$ and $\mathrm{Al}^{3+} . \mathrm{P}$ can be found in complexes with iron oxides or as iron phosphate minerals, such as vivianite or strengite (Wilfert et al., 2015, 2018). $\mathrm{Ca}^{2+}$ or $\mathrm{Mg}^{2+}$ can also form stable precipitates with $\mathrm{P}$, and calcium phosphate precipitation in the form of apatite often takes place in EBPR systems (Manas et al., 2011; Zhang et al., 2015). Moreover, these cations are also involved in the PAO metabolism and intervene stabilizing the intracellular poly-P chains (Schonborn et al., 2001; Zhang et al., 2015). Struvite $\left(\mathrm{NH}_{4} \mathrm{MgPO}_{4} \cdot 6 \mathrm{H}_{2} \mathrm{O}\right)$ is also a potential precipitate of $\mathrm{P}$, and its accumulation in the pipes can create operational problems in the plants, causing an increase of the maintenance costs (Charles et al., 2006). However, its use for $P$ recovery has been recently exploited, with the development of 
struvite precipitation from sludge or anaerobic digesters and its direct application as fertilizer (Yuan et al., 2012).

\section{Characterization of P-pools by sequential P fractionation}

To obtain an overview of the major P-pools in the four sludge samples, a sequential $\mathrm{P}$ fractionation was carried out (Figure 2, Table S4). Total P in the solid fraction was in the range of 31- 44 $\mathrm{mgP} / \mathrm{gSS}$, and was dominated by inorganic $\mathrm{P}$, extracted mainly in the BD-P and $\mathrm{NaOH}-\mathrm{P}$ pools, which constituted $13-22$ and 3-7 mgP/gSS, respectively, accounting together for $57-77 \%$ of the total $\mathrm{P}$. The BD-P fraction is usually constituted by reducible species of $\mathrm{Fe}$ and $\mathrm{Mn}$ (Roske and Schonborn, 1994). The molar Fe:P ratio, calculated using the results obtained with ICP-OES (Table 1), was in the range of $0.31-1.15$, much lower than the expected for $\mathrm{P}$ bound to Fe hydroxides (8.4 molar ratio) (Jensen et al., 1992) in all plants, and even lower than in common precipitates such as strengite $\left(\mathrm{FePO}_{4} \cdot 2 \mathrm{H}_{2} \mathrm{O}\right)$ and vivianite $\left(\mathrm{Fe}_{3}\left(\mathrm{PO}_{4}\right)_{2} \cdot 8 \mathrm{H}_{2} \mathrm{O}\right)$ of $1: 1$ and 1.5:1, respectively (Wilfert et al., 2015, 2018), with the only exception of Aalborg West. Thus, the BD extract was not specific for extracting $\mathrm{P}$ bound to amorphous Fe hydroxides solely. One likely reason for this could be release of bacterial poly-P under the reducing conditions in the $\mathrm{BD}$ extract, as previously reported (Uhlmann et al., 1990).

Biogenic $\mathrm{P}$ (organic $\mathrm{P}$ and poly-P) was mainly extracted in the nrP pool, which accounted for 8-16 $\mathrm{mgP} / \mathrm{gSS}$ (30-38\% of total P). Such high nrP fraction was expected due to the abundance of microbial biomass responsible for the EBPR process, which contains poly-P, in addition to DNA-P, RNA-P, phospholipids, and pyro-P. The presence of large amounts of poly-P was confirmed by solution ${ }^{31} \mathrm{P}$ NMR (see below), with similar results to previous findings (Roske and Schonborn, 1994; Uhlmann et al., 1990). Generally, the nrP quantified by ${ }^{31} \mathrm{P}$ NMR spectroscopy (the sum of organic P species, pyro-P, and poly-P) was slightly higher than the nrP pool from the fractionation (Figure 2, Table S4), most likely due to extraction bias or degradation of poly-P during BD-P extraction, as previously mentioned. 


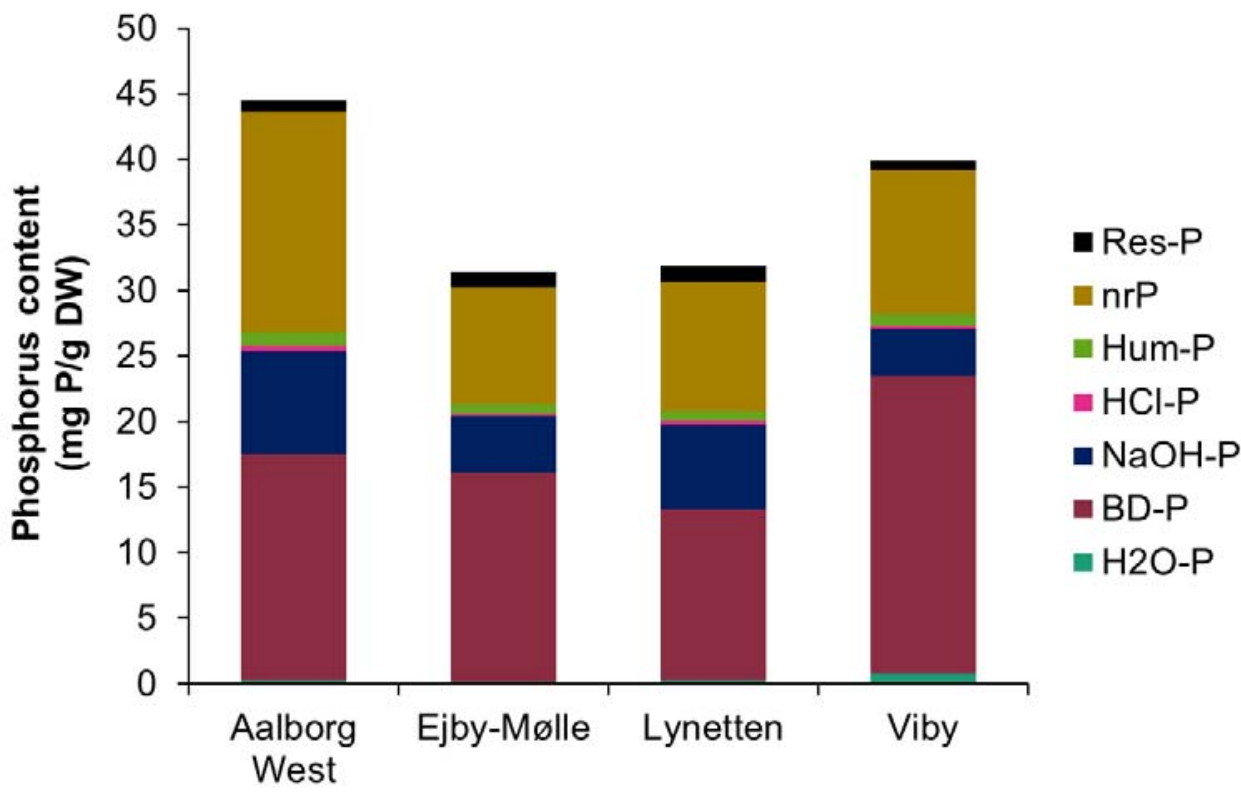

Figure 2. Extraction of P-fractions in activated sludge from 4 EBPR plants. The fraction $\mathrm{H}_{2} \mathrm{O}-\mathrm{P}$ (water extractable $\mathrm{P})$ is generally constituted by pore water $\mathrm{P}$ and loosely adsorbed $\mathrm{P}(<1 \%$ of total $\mathrm{P})$. The BD-P (reductant soluble $\mathrm{P}$ ) fraction is generally constituted by $\mathrm{P}$ bound to reducible species of $\mathrm{Fe}$ and $\mathrm{Mn}$ (inorganic fraction). The NaOH-P $(\mathrm{NaOH}$ soluble $\mathrm{P})$ liberates $\mathrm{P}$ from compounds susceptible to anion exchange of $\mathrm{PO}_{4}{ }^{3-}$ with $\mathrm{OH}^{-}$(e.g., $\mathrm{Al}$ oxides, $\mathrm{Fe}$ oxides or clay minerals). The $\mathrm{HCl}-\mathrm{P}(\mathrm{HCl}$ soluble $\mathrm{P}$ ) fraction mainly consists of inorganic $\mathrm{P}$, bound to $\mathrm{Ca}$ and $\mathrm{Mg}$. Hum-P (Humic acid $\mathrm{P}$ ) is constituted by $\mathrm{P}$ bound to humic acids. The nrP (non-reactive $\mathrm{P}$ ) fraction is calculated by subtracting the $\mathrm{H}_{2} \mathrm{O}-\mathrm{P}$, the BD-P, and the NaOH-P from total $\mathrm{P}$ and contains the majority of the organic P. Res-P (residual P) is constituted by hardly degradable organic $\mathrm{P}$ compounds and $\mathrm{P}$ compounds that are not extracted in the previous steps (e.g., hematite).

\section{Characterization of the bacterial biomass}

The bacterial biomass is an important part of the activated sludge, and we wanted to make a comprehensive P mass-balance for this fraction. We applied a microscopy-based approach, which included number of cells in the activated sludge, their sizes, and their content of poly-P (see next section). Several studies have previously attempted to quantify the number and size of bacterial cells in wastewater and activated sludge (Table 2). The preferred method is staining with fluorescent dyes that bind to the cells' DNA, such as DAPI or acridine orange (AO), followed by epifluorescence microscopy. Different studies have reported cell numbers in the range of $2.0 \times 10^{11}$ $-26.3 \times 10^{11}$ cells/gVSS (Table 2) (Cloete and Africa, 1988; Frølund et al., 1996; Nielsen and Nielsen, 2002; Rasmussen et al., 1994; Urban et al., 1993; Vollertsen et al., 2001). More recently, flow cytometry has been used for rapid and direct quantification of bacterial cells in activated sludge, with similar results, in the range of $2.7 \times 10^{11}-11.0 \times 10^{11}$ cells/gVSS (Foladori et al., 2010; Ma et al., 2013). In our study, the average number of cells obtained by DAPI staining and epifluorescence microscopy provided results in the same range of $3.78-6.46 \times 10^{11}$ cells $/ \mathrm{gVSS}$, and very similar for all four EBPR plants (Table 2). 
The biovolume of bacteria in wastewater treatment systems has been quantified by fluorescence microscopy (Frølund et al., 1996) or flow-cytometry (Foladori et al., 2010), both providing average cell biovolume of $0.16-0.43 \mu \mathrm{m}^{3}$. However, these estimates do not take into consideration filamentous bacteria which typically constitute $10-20 \%$ of the biomass (Nierychlo et al., 2020). Therefore, the biovolumes were measured separately for spherical/rod-shaped cells and filamentous microorganisms. In accordance with previous findings, the average biovolume of spheroidal/rodshaped cells for the 4 plants was $0.363 \pm 0.240 \mu \mathrm{m}^{3}$, while the filaments biovolume was approximated to $0.608 \pm 0.245 \mu^{3}$ with no difference between the plants. The average length of the cells within the filaments were assumed to be $1 \mu \mathrm{m}$, as it is difficult to measure the real dimension of cells inside filamentous bacteria (Eikelboom, 1975; Van Veen, 1973; Ziegler et al., 1990).

\section{Quantification of total poly-P by different methods}

Since intracellular poly-P content is regarded difficult to analyse reliably, we have applied several independent analytical tools for its absolute quantification. During anaerobic P-release experiment, active PAOs release most of their poly-P as soluble phosphate in presence of a substrate. Hence, the amount of $\mathrm{P}$ released during this phase was compared to the change in intracellular poly-P content obtained by Raman microspectroscopy, ${ }^{31} \mathrm{P}$ MAS NMR for total poly-P in the sludge, and ${ }^{31} \mathrm{P}$ solution state NMR after extraction (Table 3). All methods have recently shown to be successful in quantifying poly-P in activated sludge (Fernando et al., 2019; Staal et al., 2019a).

P-release test. Anaerobic P-release experiments with fresh activated sludge from the four EBPR plants were carried out to quantify the intracellular poly-P before and after anaerobic release. A mixture of different substrates, comprising acetate, glucose, and casamino acids, was used as carbon source during the experiment, to supply for a large fraction of different PAOs such as $C a$. Accumulibacter, Tetrasphaera, and Dechloromonas (Marques et al., 2017; Petriglieri et al., 2020; Qiu et al., 2019). Similar P-release patterns were observed in all the four plants, with maximum $P$ release after $3 \mathrm{~h}$ in the range of $8-13 \mathrm{mg} \mathrm{P} / \mathrm{gSS}$ (Figure 3A, Table 3) in Lynetten, Ejby-Mølle, and Viby (Figure 3A). These values were similar to those previously obtained in Danish EBPR plants of 8-15 mg P/gSS (Mielczarek et al., 2013). The highest P release of $27.4 \pm 0.9 \mathrm{mg} / \mathrm{gSS}$ was observed in Aalborg West, corresponding to the higher abundance of PAOs in this plant.

Raman microspectroscopy. Raman microspectroscopy was applied to estimate the amount of intracellular poly-P present in 1,500 randomly selected bacterial cells in the fresh activated sludge by combining Raman and DAPI staining. The total amount varied between the plants, with lowest content observed in Viby $(10.2 \mathrm{mg} / \mathrm{gSS})$ and highest in Aalborg West (27.1 mg/gSS) (Figure 3B, Table 3-4). A drastic decrease of intracellular poly-P was observed after the $3 \mathrm{~h}$ anaerobic conditions in sludge from all plants, reaching values of $1.72-2.72 \mathrm{mg} / \mathrm{gSS}$, corresponding to 10 $16 \%$ of the poly-P released (Figure 3B, Table 4). The difference in total poly-P content measured by Raman corroborated well with the P-released during anaerobic batch experiment (Figure $3 \mathrm{~A}$ and Table 3), and with quantifications by ${ }^{31} \mathrm{P}$ solution state NMR and ${ }^{31} \mathrm{P}$ MAS NMR (Table 3, see below). 
A

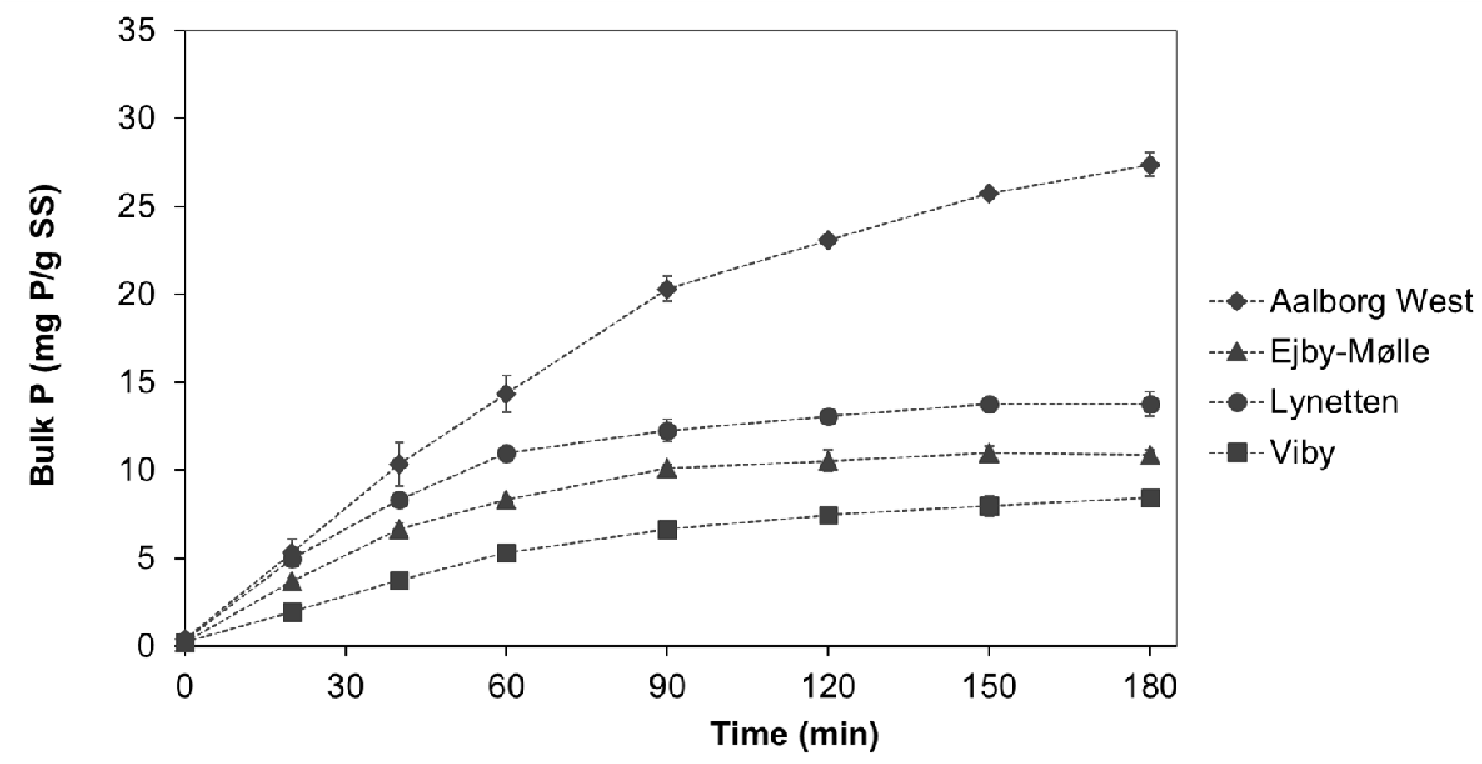

B

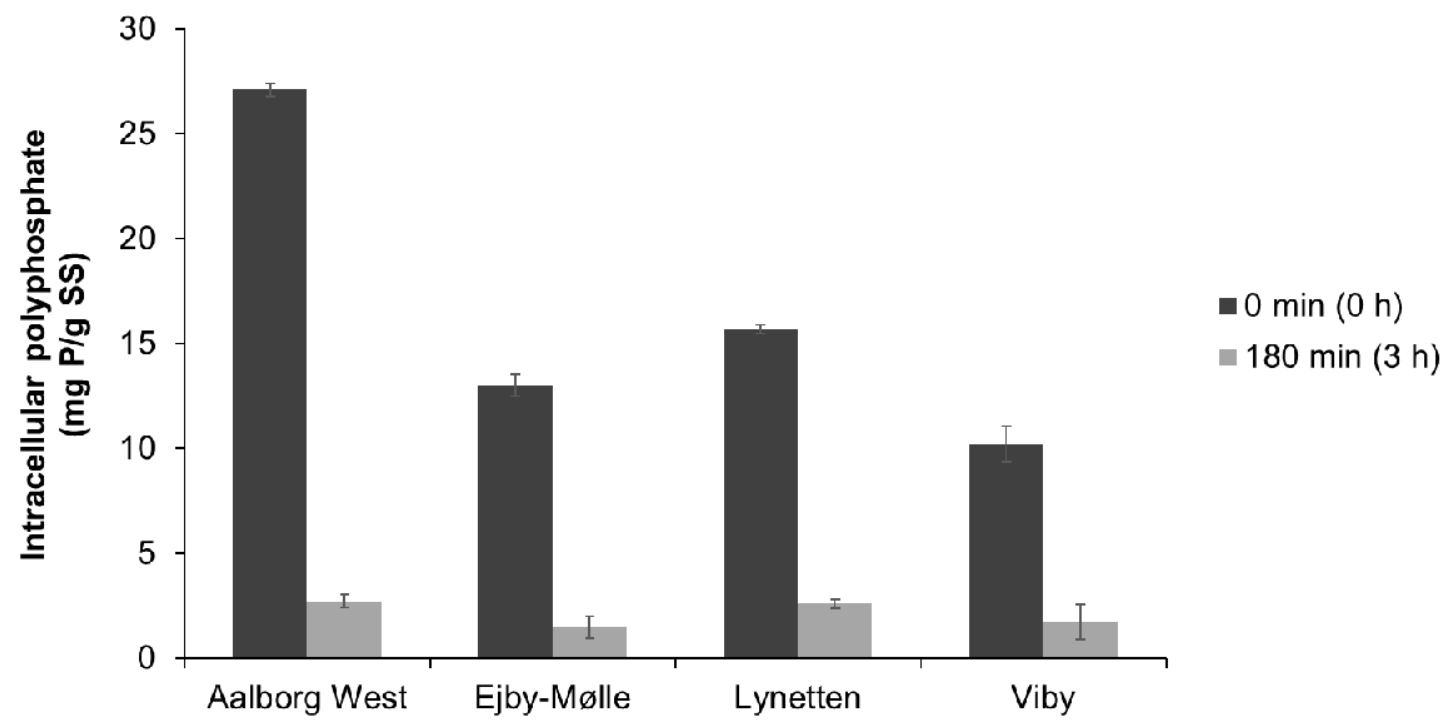

Figure 3. A) Bulk ortho-P concentration during the anaerobic P-release experiments with activated sludge from the four WWTPs. B) Total intracellular polyphosphate measured as an average of 1,500 randomly selected microbial cells by Raman microspectroscopy in initial samples $(0 \mathrm{~h})$ and after anaerobic P-release (3 h).

Interestingly, $25-32 \%$ of the bacterial cells analysed contained high amounts of poly-P (Figure 4). Among these, a fraction (5-8\%) contained high amounts of poly-P also after the anaerobic incubation, thus not behaving as canonical PAOs. These may utilize other substrates or they did not show a dynamic P-cycling as observed in canonical PAOs. These could be microorganisms such as the filamentous $\mathrm{Ca}$. Microthrix that can contain large amount of $\mathrm{P}$, but do not show a typical $\mathrm{P}$ 
uptake-release dynamics (Wang et al., 2014b). Interestingly, comparison of these fractions to qFISH or amplicon sequencing results (Table 5), where the measured fraction of known PAO comprised $12-19 \%$ of the total number of bacteria, indicates that there is still up to $10 \%$ of unknown PAOs in the activated sludge samples analysed. Additionally, the lack of poly-P release in 5-10\% of the cells corroborates well with the abundance of $\mathrm{Ca}$. Microthrix, which was measured by qFISH to comprise $1.5-7.3 \%$ of the total number of bacteria. This shows that not only well-recognized PAOs such as $\mathrm{Ca}$. Accumulibacter are important for P-removal, but also other unconventional "PAOs" such as $\mathrm{Ca}$. Microthrix may be of key importance.
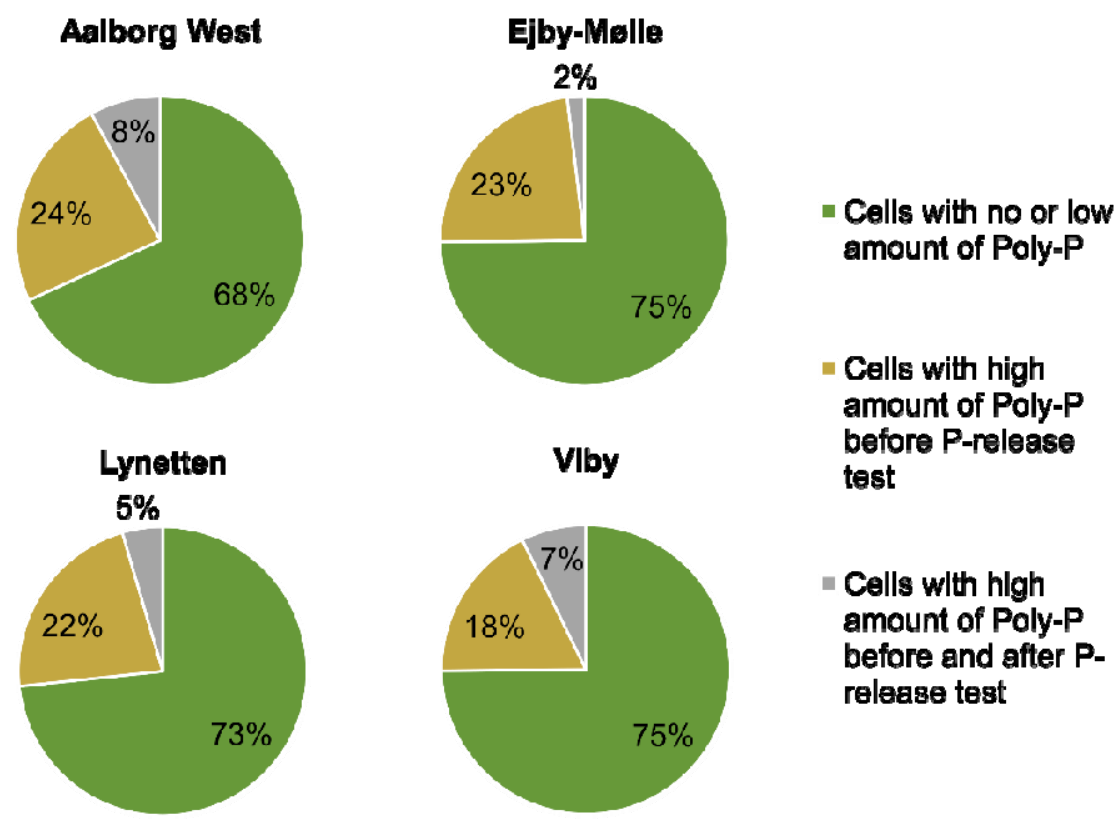

Figure 4. Abundance distribution of bacterial cells in activated sludge with different content of intracellular poly-P. Intracellular poly-P was measured by Raman microspectroscopy in 1,500 random DAPI stained bacterial cells before and after anaerobic P-release in the 4 full-scale plants.

Poly-P pools measured by ${ }^{31} P$ solution state $N M R$ and ${ }^{31} P$ MAS NMR. Two different, but complementary, NMR-based approaches were used to calculate the total amount of poly-P in the four activated sludge samples. While ${ }^{31} \mathrm{P}$ MAS NMR is used to quantify all poly-P middle groups, solution state ${ }^{31} \mathrm{P}$ NMR is also showing other organic-bound $\mathrm{P}$ forms, as well as poly-P end groups (Staal et al., 2019). Their combined application ensures a higher accuracy in the quantification and allows the retrieval of information regarding important organic $\mathrm{P}$ species, such as DNA and phospholipids.

According to solution state ${ }^{31} \mathrm{P}$ NMR (Table 3), poly-P constituted $8.8-22.2 \mathrm{mgP} / \mathrm{gSS}$, which is in the similar range as previous findings of approx. $13 \mathrm{mgP} / \mathrm{gSS}$ (Staal et al., 2019), and in accordance to the amounts measured by P-release tests (8-27 mgP/gSS) and Raman microspectroscopy (10-27 $\mathrm{mgP} / \mathrm{gSS}$ ). In all plants, the solution state ${ }^{31} \mathrm{P}$ NMR spectra of the initial samples (time $=0 \mathrm{~h}$, 
aerobic phase) showed large peaks located at $\left(\delta\left({ }^{31} \mathrm{P}\right) \approx-25 \mathrm{ppm}\right.$ originating from poly-P middle groups. There were also signals at $\left(\delta\left({ }^{31} \mathrm{P}\right) \approx-5 \mathrm{ppm}\right.$ originating from poly-P end groups or pyrophosphate (Figure 5, Figures S1-S3), which would not be shown with the solely use of ${ }^{31} \mathrm{P}$ MAS NMR, due to line broadening. These large peaks indicate the presence of large amounts of poly-P in the microbial biomass. In accordance with the results from the P-release experiment and the Raman analysis, the poly-P peaks were not present in the spectra of samples analysed after anaerobic release (time $=3 \mathrm{~h}$ ) (Figure 5, Figures S1-S3), confirming the sensitivity of the methods and the dynamic levels of this poly-P in the PAO community.

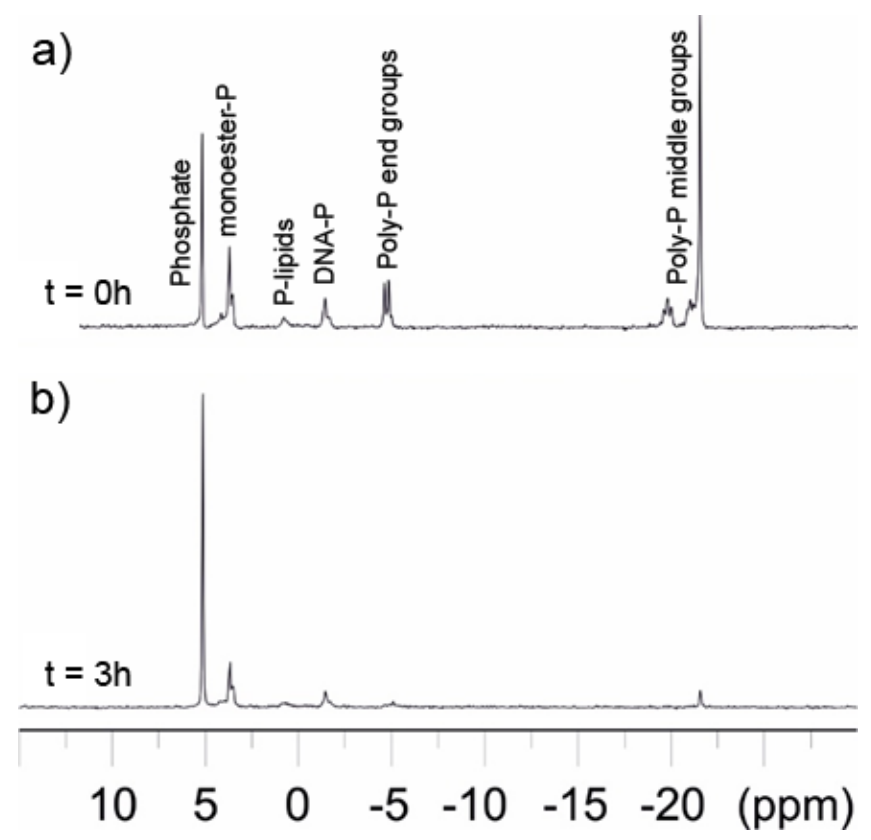

Figure 5. ${ }^{31} \mathrm{P}$ solution NMR spectra of the Ejby-Mølle samples at time 0 (a) and after $3 \mathrm{~h}$ anaerobic P-release test (b).

The utilization of solution state ${ }^{31} \mathrm{P}$ NMR is also supplying valuable information regarding other biologically-bound $\mathrm{P}$ forms, such as DNA-P and P-lipids, normally present in bacterial cells as component of their membranes or genome. DNA-P was found in the biomass from all four WWTP in the range of 1.2-1.4 mg DNA-P/gSS (Table 6), which is similar to previous results found in pure cultures, in the range of 0.39 - $2.78 \mathrm{mg}$ DNA-P/SS (Makarov et al., 2002). The same study also reports a total $\mathrm{P}$ content of $15-18 \mathrm{mgP} / \mathrm{g}$ SS for pure cultures, which is consistent with common $\mathrm{P}$ content in non-EBPR sludge of 5-15 mgP/g SS (Jensen et al., 2015; Menar and Jenkins, 1970; Metcalf \& Eddy Inc. et al., 2014). Similarly, lipid-P values were approx. 0.5-0.6 mg DNA-P/gSS (Table 6), in the range of previously reported measurements of $0.26-9.32$ for pure bacterial cultures obtained by NMR or other methods (Makarov et al., 2002; Op Den Kamp et al., 1969; Pinkart and White, 1997). 
The ${ }^{31} \mathrm{P}$ MAS NMR spectra (Figure S4) of the four initial samples (time $=0 \mathrm{~h}$, aerobic phase) confirmed the results obtained by other methods, showing the spinning sideband manifold of two broad resonances located $\left(\delta\left({ }^{31} \mathrm{P}\right) \approx-2\right.$ and $-25 \mathrm{ppm}$, which originate from ortho- and poly-P, respectively. After $3 \mathrm{~h}$, the poly-P concentration was below the detection limit for Ejby-Mølle, Viby, and Lynetten, implying full degradation of poly-P, whereas for Aalborg West ca. 9\% of the total intensity was from pyro-P (Table S5). The Aalborg West sample was different from the other three plants as it had the highest concentration of $\mathrm{P}(14 \mathrm{mg} / \mathrm{gSS})$. We note that ${ }^{31} \mathrm{P}$ present in magnetic phases such as iron phosphate minerals formed e.g., by addition of Fe(III) salts to the plant, will not be observed under the experimental conditions used, as recently discussed (Staal et al., 2019). There was a small (2-4 ppm) shift in the centre of gravity of the ortho-P resonance, which contains contributions from both inorganic and organic species after $3 \mathrm{~h}$, implying that the speciation of ortho-P in the sludge changed during the release experiment. At $0 \mathrm{~h}$ this resonance is a mixture of the different inorganic and organic orthophosphate, whereas inorganic P-phases such as magnesium and calcium $\mathrm{P}$ prevailed at $3 \mathrm{~h}$, due to the release of biological $\mathrm{P}$.

\section{PAO community profiling}

Community profiling of the four activated sludges was performed by $16 \mathrm{~S}$ rRNA amplicon sequencing, and FISH-based quantification was used to confirm the relative abundances obtained for target organisms (Table 5). According to the sequencing results, activated sludge in all the plants comprised a large community of PAOs, with Tetrasphaera being the most abundant. However, FISH (Figure 6, Table 5) showed that Ca. Accumulibacter and Dechloromonas had a larger relative biovolume $(1.0-5.7 \%)$ in all plants but Aalborg West, showing the difference in quantifying biomass by the two methods due to differences in extraction efficiency, primer bias, 16S rRNA gene copy number, and cell size (Albertsen et al., 2015). Furthermore, both amplicon and FISH showed that the non-conventional PAO $\mathrm{Ca}$. Microthrix had a large relative biovolume $(1.5-7.3 \%)$ in all plants, contributing significantly to the P-removal. 

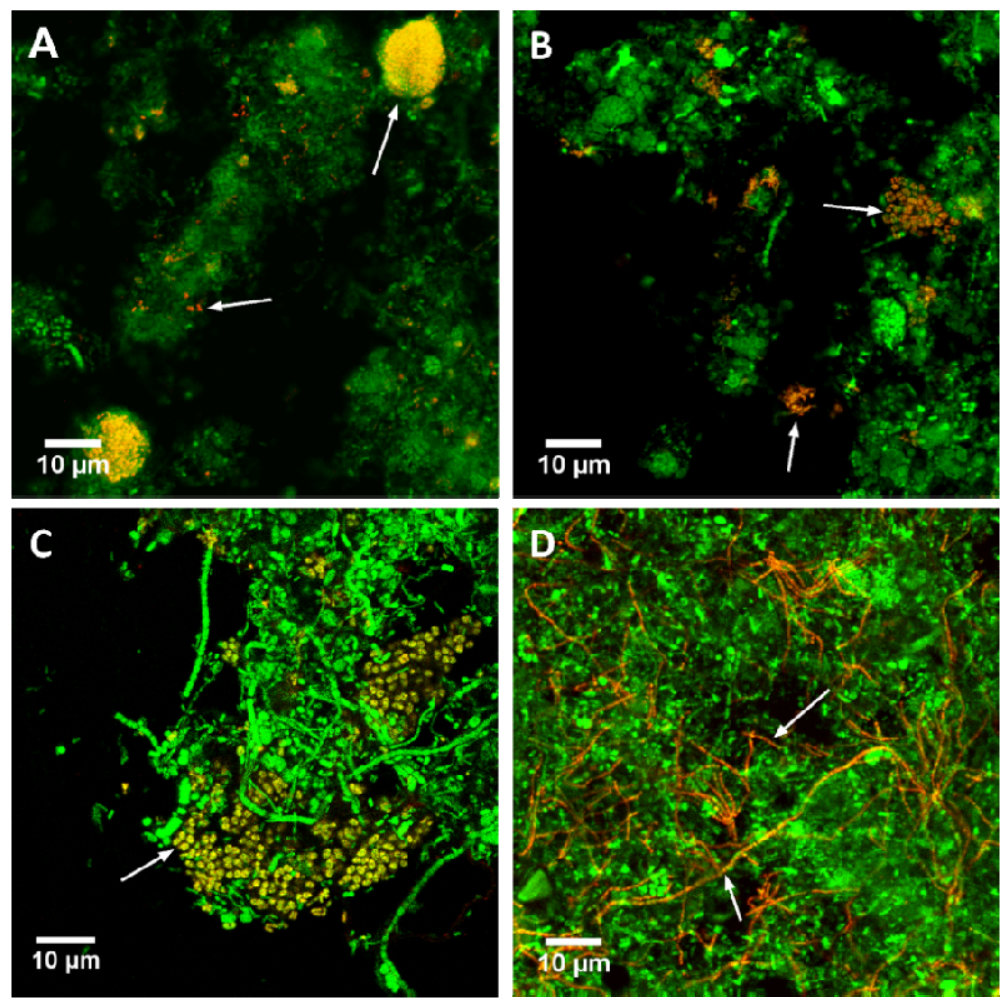

Figure 6. Composite FISH micrographs of PAOs in the four full-scale activated sludges. A) Specific probes (red) targeting two most abundant Dechloromonas species. B) Specific probes (red) targeting the Tetrasphaera genus. C) Specific probe (red) targeting $C a$. Accumulibacter. D) Specific probe (red) targeting the con-conventional PAO Ca. Microthrix. All bacteria were targeted by EUBmix probe (green) in all images, while target bacteria appear in orange-yellow.

\section{Quantification of the main storage polymers in PAOs in full-scale EBPR plants}

FISH-Raman was used to determine the level and dynamics of storage polymers accumulated by the known probe-defined PAOs. Moreover, the filamentous $\mathrm{Ca}$. Microthrix, known to accumulate poly$\mathrm{P}$, but not releasing it rapidly during anaerobic conditions, was also included in the analysis. While the typical values calculated for rod-shaped cells like Tetrasphaera and $\mathrm{Ca}$. Accumulibacter refer to the amount of poly-P present in a single cell, the values measured for $\mathrm{Ca}$. Microthrix refer to a biovolume of a filament with an average $0.72 \mu \mathrm{m}$ width and $1 \mu \mathrm{m}$ length. The intracellular content of poly-P, PHA, and glycogen was very similar in the same probe-defined species of PAOs across different plants (Table 7-S6).

The dynamics and levels of storage polymers in PAOs in Ejby-Mølle plant are shown as an example in Figure 6 (other plants, see Table 7-8). The amount of poly-P (g/cell) (Figure 7A) was in the range of $10-15 \times 10^{-14}, 6.2-6.9 \times 10^{-14}, 1.0-1.8 \times 10^{-14}, 1.1-2.2 \times 10^{-14}$ for Ca. Accumulibacter, Dechloromonas, Tetrasphaera, and $\mathrm{Ca}$. Microthrix, respectively. The amount calculated in this study for the wellknown PAOs $C a$. Accumulibacter and Tetrasphaera is lower than we measured in a previous study applying similar approach (Fernando et al., 2019). 

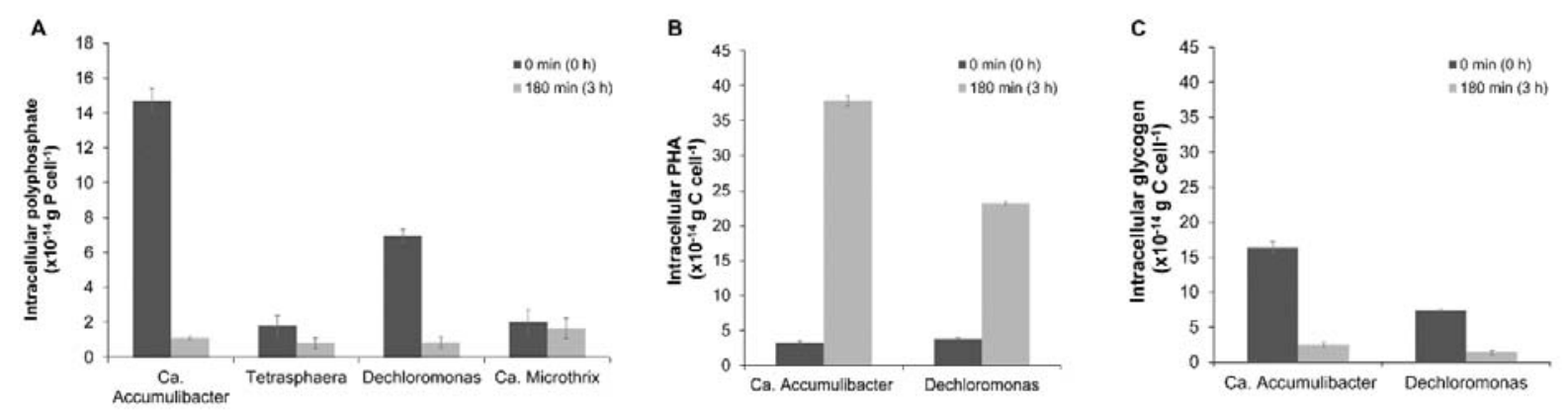

Figure 7. Dynamics of the storage polymers poly-P, PHA, and glycogen in important PAOs in activated sludge. Data from Ejby-Mølle WWTP is shown as example. (A) Poly-P levels during aerobic phase $(0 \mathrm{~h})$ and after anaerobic P-release (3 h) in known PAOs and in the unconventional PAO Ca. Microthrix. (B) PHA levels in $\mathrm{Ca}$. Accumulibacter and Dechloromonas cells. No PHA was detected in Tetrasphaera and $\mathrm{Ca}$. Microthrix. (C) Glycogen levels in $\mathrm{Ca}$. Accumulibacter and Dechloromonas cells. No glycogen was detected in Tetrasphaera and Ca. Microthrix.

This difference is caused by an overestimation of the cell area by Fernando et al., (2019), as cell sizes from pure cultures or enrichments were extrapolated to full-scale plants. In this study, the area of the cells measured in situ were smaller, resulting in a lower amount of poly-P per cell. In all three conventional PAOs, poly-P was hydrolysed and ortho-P released into the bulk liquid during the anaerobic incubation. Considering only the poly-P amount accumulated intracellularly per cell, $\mathrm{Ca}$. Accumulibacter had the largest amount due to its larger size (Table S7). However, when looking at the average amount of poly-P in the cells $\left(\mathrm{g} / \mu^{3}{ }^{3}\right)$, the three conventional PAOs had almost similar content, in average $4.5 \times 10^{-14}, 3.9 \times 10^{-14}$ and $2.8 \times 10^{-14}$ for $C a$. Accumulibacter, Tetrasphaera, and Dechloromonas, respectively. Moreover, in the plants investigated, all PAOs were highly abundant and, therefore, had a significant contribution to P-removal. As expected, $\mathrm{Ca}$. Microthrix released only a small amount of poly-P during the $3 \mathrm{~h}$ anaerobic conditions. Although the cell width is relatively small, and thus also the P-content per $\mu \mathrm{m}$, they can be a significant contributors to $\mathrm{P}$ removal with filaments length exceeding $100 \mu \mathrm{m}$ (Blackall et al., 1996).

Ca. Accumulibacter and Dechloromonas cells possessed a dynamic behaviour of intracellular PHA and glycogen (Figure 7B-C, Table S7), as previously described (Fernando et al., 2019; Petriglieri et al., 2020) In both organisms, the $\mathrm{C} / \mathrm{P}$ and $\mathrm{C} / \mathrm{C}$ ratio were within the range of $0.3-0.4$, in accordance with the accepted metabolic model for conventional PAOs and previous studies (Marques et al., 2017; Qiu et al., 2019). No glycogen and PHA were detected in Tetrasphaera and Ca. Microthrix, in accordance with their current metabolic models and previous findings (Fernando et al., 2019; McIlroy et al., 2013).

\section{A comprehensive P mass-balance}

The combination of the data from ICP-OES, Raman analysis, solution state and solid state ${ }^{31} \mathrm{P}$ MAS NMR, allowed us to obtain a very comprehensive and robust mass-balance of P-fractions in activated sludge from the four EBPR plants (Figure 8). Inorganic P, calculated by subtracting all the other measured fractions from the total $\mathrm{P}$, was the biggest fraction in all plants except Aalborg 
West, constituting $38-69 \%$ of the total P. In Viby more than $70 \%$ of the total $\mathrm{P}$ was bound as inorganic P, most likely linked to iron or aluminium. A closer inspection of the operation in Viby revealed substantial addition of $\mathrm{Fe}$ (III) salts in the period before sampling, which could explain its poor EBPR performance at the time of sampling. According to the sequential $\mathrm{P}$ fractionations, the $57-77 \%$ of the $\mathrm{P}$ was in the inorganic fraction (mainly BD-P and $\mathrm{NaOH}-\mathrm{P}$ fractions). The difference of these values, compared to those that can be extrapolated by solution ${ }^{31} \mathrm{P}$ NMR, ${ }^{31} \mathrm{P}$ MAS NMR spectroscopy, and Raman microspectroscopy measurements, were most likely due to extraction bias or degradation of poly-P during BD-P extraction.

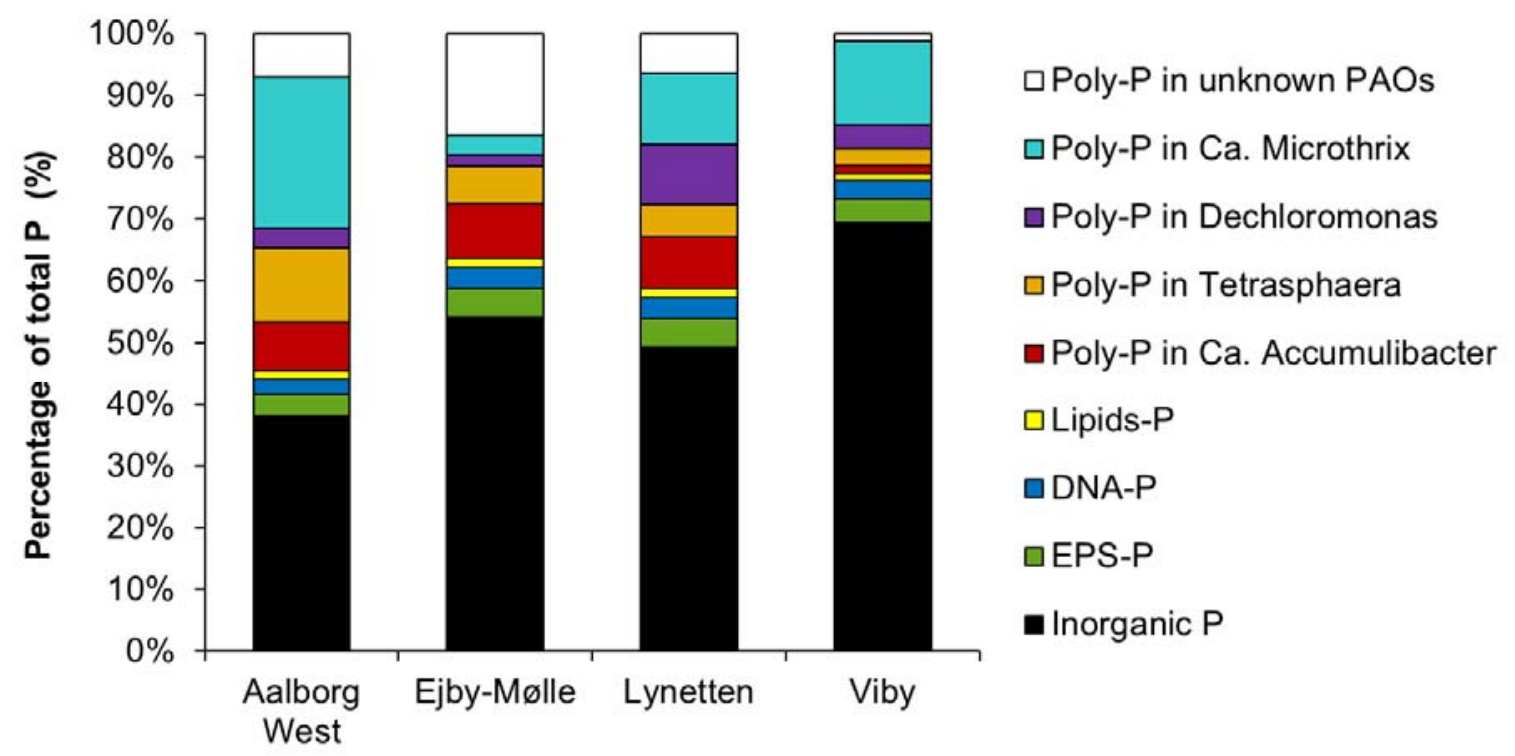

Figure 8. Comprehensive P-mass balance in the activated sludge. Distribution (in percentage) of P pools in activated sludge in the aeration tanks of four full-scale EBPR plants.

In all the plants, a large part of total $\mathrm{P}$ was present as organically-bound $\mathrm{P}$, and a natural part of the microbial biomass, such as DNA-P or membrane lipids, or included into the EPS (Zhang et al., 2013a). Solution state ${ }^{31} \mathrm{P}$ NMR provided valuable quantification of these distinct fractions, with DNA-P and lipid-P of approx. 1.7-1.9 mg P/gSS, constituting together 3-4\% of total P (Figure 8). Previous studies on P speciation in the EPS have reported EPS-P values in the range of 0.9-2.1 $\mathrm{mg}$ P/gSS (Li et al., 2010; Zhang et al., 2013a, 2013b), which would account for 3-4\% of the total P (Figure 8).

The second largest fraction in all plants but Viby was poly-P, constituting $22-54 \%$ of total P (Figure 8). Even though there were some variations between the independent methods applied for total poly-P quantification, all of them provided a good estimation of the poly-P content in the different samples and could therefore be independently used in further studies.

Interestingly, approx. 25\% (and up to $32 \%$ ) of all bacterial cells in the activated sludge accumulated large amounts of poly-P, being either PAOs or non-conventional PAOs. In all four plants, the three 
PAO genera investigated ( $\mathrm{Ca}$. Accumulibacter, Tetrasphaera, and Dechloromonas) were important for P-removal, and qFISH demonstrated that the known PAOs accounted for 19-20\% of the biomass accumulating poly-P, leaving 12-14\% undescribed. However, the results showed that most of these $(2-8 \%)$ could be explained by the non-conventional PAO, Ca. Microthrix. Non-conventional PAOs are easily overlooked since they do not exhibit the dynamic $\mathrm{P}$ release/uptake in typical tests for PAO activity. In general, the contribution of the known PAO genera varied from plant to plant, depending on their relative abundances. The contribution of $\mathrm{Ca}$. Microthrix exceeded the other known PAOs in three plants (Aalborg West, Lynetten, and Viby) because of its high abundance. This filamentous bacterium is considered unwanted because it causes settling (bulking) or foaming problems in full-scale WWTPs (Nierychlo et al., 2020), but this study also shows that they should also be regarded as important contributors to P removal in EBPR systems. Considering this nonconventional PAO, the mass-balance shows that only a small fraction of total poly-P (1-13\%) was accumulated by PAOs that are still undescribed, indicating that most important PAOs are now known in the plants investigated.

\section{Concluding remarks}

The activated sludge samples, taken from the four largest EBPR plants in Denmark, had a total P content of $36-50 \mathrm{mgP} / \mathrm{gSS}$, and in all of them, except one, a substantial fraction of P (31-62\%) was part of the biomass in the form of organic $\mathrm{P}$ and poly-P. The total amount of poly-P was successfully measured by several independent methods. Extensive analyses of number and sizes of all bacterial cells and specific FISH probe-defined PAOs allowed us to quantify the individual contribution of the known PAOs, Ca. Accumulibacter, Tetrasphaera, and Dechloromonas to P removal. In addition, the non-conventional PAO $\mathrm{Ca}$. Microthrix contained large amounts of poly-P contributing considerably to P-removal. The distribution of poly-P in random bacterial cells showed that cells with high content of poly-P constituted $25-32 \%$ of all cells. Only a small amount of poly$\mathrm{P}(1-13 \%)$ could not be assigned to any known PAO, indicating that most of the important PAOs in the plants investigated were described.

\section{Acknowledgements}

We thank Susanne Bielidt for assistance with cell counting and microscopical analysis. The project was funded by the Villum Foundation (Dark Matter, grant 13351) and Innovation Fund Denmark (ReCoverP, grant 4106-00014B).

\section{References}

Adam, C., Peplinski, B., Michaelis, M., Kley, G., Simon, F., 2009. Thermochemical treatment of sewage sludge ashes for phosphorus recovery. Waste Manag. 29, 1122-1128.

https://doi.org/10.1016/j.wasman.2008.09.011

Albertsen, M., Karst, S.M., Ziegler, A.S., Kirkegaard, R.H., Nielsen, P.H., 2015. Back to basics The influence of DNA extraction and primer choice on phylogenetic analysis of activated sludge communities. PLoS One 10, 1-15. https://doi.org/10.1371/journal.pone.0132783 
Amann, R.I., Binder, B.J., Olson, R.J., Chisolm, S.W., Devereux, R., Stahl, D.A., 1990.

Combination of 16S rRNA-targeted oligonucleotide probes with flow cytometry for analyzing mixed microbial populations. Appl Env. Microbiol 56, 1919-1925.

APHA, AWWA, WEF, 2005. Standard Methods for the Examination of Water and Wastewater. American Public Health Association, American Water.

Blackall, L.L., Stratton, H., Bradford, D., Dot, T.D., Sjorup, C., Seviour, E.M., Seviour, R.J., 1996. "Candidatus Microthrix parvicella," a Filamentous Bacterium from Activated Sludge Sewage Treatment Plants. Int. J. Syst. Evol. Microbiol. 46, 344-346.

Charles, W., Ho, G., Costa, M., Spencer, P., 2006. Solutions to a combined problem of excessive hydrogen sulfide in biogas and struvite scaling. Water Sci. Technol. 53, 203-210.

https://doi.org/10.2166/wst.2006.198

Cloete, T.E., Africa, S., 1988. A combined membrane filter-immunofluorescent technique for the in situ identification and enumeration of Acinetobacter in activated sludge. Water Res. 22, 961-969.

Crocetti, G.R., Hugenholtz, P., Bond, P.L., Schuler, A.J., Keller, J., Jenkins, D., Blackall, L.L., 2000. Identification of polyphosphate-accumulating organisms and design of 16SrRNA-directed probes for their detection and quantitation. Appl. Environ. Microbiol. 66, 1175-1182.

https://doi.org/10.1128/AEM.66.3.1175-1182.2000.Updated

Daims, H., Brühl, A., Amann, R., Schleifer, K.H., Wagner, M., 1999. The domain-specific probe EUB338 is insufficient for the detection of all Bacteria: development and evaluation of a more comprehensive probe set. Syst Appl Microbiol 22, 434-444.

Daims, H., Lücker, S., Wagner, M., 2006. Daime, a Novel Image Analysis Program for Microbial Ecology and Biofilm Research. Environ. Microbiol. 8, 200-213. https://doi.org/10.1111/j.14622920.2005.00880.x

Daims, H., Stoecker, K., Wagner, M., 2005. Fluorescence in situ hybridization for the detection of prokaryotes, in: Osborn, A.M., Smith, C.J. (Eds.), Molecular Microbial Ecology. Taylor \& Francis, New York, pp. 213-239.

Dueholm, M.S., Andersen, K.S., McIlroy, S.J., Kristensen, J.M., Yashiro, E., Karst, S.M., Albertsen, M., Nielsen, P.H., 2020. Generation of comprehensive ecosystems-specific reference databases with species-level resolution by high-throughput full-length 16S rRNA gene sequencing and automated taxonomy assignment (AutoTax). bioRxiv 672873. https://doi.org/10.1101/672873 Dueholm, M.S., Andersen, K.S., Petriglieri, F., McIlroy, S.J., Nierychlo, M., Petersen, J.F., Kristensen, J.M., Yashiro, E., Karst, S.M., Albertsen, M., Nielsen, P.H., 2019. Comprehensive ecosystem-specific 16S rRNA gene databases with automated taxonomy assignment (AutoTax) provide species-level resolution in microbial ecology. bioRxiv 672873.

https://doi.org/10.1101/672873

Egle, L., Rechberger, H., Krampe, J., Zessner, M., 2016. Phosphorus recovery from municipal wastewater: An integrated comparative technological, environmental and economic assessment of P recovery technologies. Sci. Total Environ. 571, 522-542.

https://doi.org/10.1016/j.scitotenv.2016.07.019

Eikelboom, D.H., 1975. Filamentous organisms observed in activated sludge. Water Res. 9, 365388. 
Ek, M., Bergostrom, R., Bjurhem, J.-E., Bjorlenius, B., Hellstrom, D., 2006. Concentration of nutrients from urine and reject water from anaerobically digested sludge. Water Sci. Technol. 54, 437-444. https://doi.org/10.2166/wst.2006.924

Fernando, E.Y., McIlroy, S.J., Nierychlo, M., Herbst, F.-A., Petriglieri, F., Schmid, M.C., Wagner, M., Nielsen, J.L., Nielsen, P.H., 2019. Resolving the individual contribution of key microbial populations to enhanced biological phosphorus removal with Raman-FISH. ISME J. 1933-1946. https://doi.org/10.1038/s41396-019-0399-7

Foladori, P., Bruni, L., Tamburini, S., Ziglio, G., 2010. Direct quantification of bacterial biomass in influent, effluent and activated sludge of wastewater treatment plants by using flow cytometry. Water Res. 44, 3807-3818. https://doi.org/10.1016/j.watres.2010.04.027

Frølund, B., Palmgren, R., Keiding, K., Nielsen, P.H., 1996. Extraction of extracellular polymers from activated sludge using a cation exchange resin. Water Res. 30, 1749-1758.

González, M.J.J., Pérez, B.C., Fernández, G.., 2005. Analytical phosphorus fractionation in sewage sludge and sediment samples. Anal. Bioanal. Chem. 381, 873-878. https://doi.org/10.1007/s00216004-2989-z

Hupfer, M., Gloess, S., Schmieder, P., Grossart, H.P., 2008. Methods for Detection and Quantification of Polyphosphate and Polyphosphate Accumulating Microorganisms in Aquatic Sediments. Internat. Rev. Hydrobiol. 93, 1-30. https://doi.org/10.1002/iroh.200610935 Jensen, H.S., Kristensen, P., Jeppesen, E., Skytthe, A., 1992. Iron:phosphorus ratio in surface sediment as an indicator of phosphate release from aerobic sediments in shallow lakes. Hydrobiologia 235, 731-743. https://doi.org/10.1007/BF00026261

Jensen, M.D., Tychsen, P., Thomsen, M., Martinsen, L., Hasler, B., 2015. Bæredygtig udnyttelse af fosfor fra spildevand. Miljøprojekt nr. 1661. Miljøstyrelsen, Miljøministeriet, Denmark.

Jørgensen, M.K., Nierychlo, M., Nielsen, A.H., Larsen, P., Christensen, M.L., Nielsen, P.H., 2017. Unified understanding of physico-chemical properties of activated sludge and fouling propensity. Water Res. 120, 117-132. https://doi.org/10.1016/j.watres.2017.04.056

Kong, Y., Nielsen, J.L., Nielsen, P.H., 2005. Identity and Ecophysiology of Uncultured Actinobacterial Polyphosphate-Accumulating Organisms in Full-Scale Enhanced Biological Phosphorus Removal Plants. Appl. Environ. Microbiol. 71, 4076-4085.

https://doi.org/10.1128/AEM.71.7.4076-4085.2005

Kong, Y., Xia, Y., Nielsen, J.L., Nielsen, P.H., 2007. Structure and function of the microbial community in a full-scale enhanced biological phosphorus removal plant. Microbiology 153, 40614073. https://doi.org/10.1099/mic.0.2007/007245-0

Lee, S., Fuhrman, J.E.D.A., 1987. Relationships between Biovolume and Biomass of Naturally Derived Marine Bacterioplanktont. Appl. Environ. Microbiol. 1298-1303.

Li, N., Ren, N., Wang, X., Kang, H., 2010. Effect of temperature on intracellular phosphorus absorption and extra-cellular phosphorus removal in EBPR process. Bioresour. Technol. 101, 62656268. https://doi.org/10.1016/j.biortech.2010.03.008

Liu, X., Sheng, H., Jiang, S., Yuan, Z., Zhang, C., Elser, J.J., 2016. Intensification of phosphorus cycling in China since the 1600s. PNAS 113, 2609-2614. https://doi.org/10.1073/pnas.1519554113 
Ma, L., Mao, G., Liu, J., Yu, H., Gao, G., Wang, Y., 2013. Rapid quantification of bacteria and viruses in influent, settled water, activated sludge and effluent from a wastewater treatment plant using flow cytometry. Water Sci. Technol. 68.8, 1763-1769. https://doi.org/10.2166/wst.2013.426 Majed, N., Chernenko, T., Diem, M., Gu, A.Z., 2012. Identification of functionally relevant populations in enhanced biological phosphorus removal processes based on intracellular polymers profiles and insights into the metabolic diversity and heterogeneity. Environ. Sci. Technol. 46, 5010-5017. https://doi.org/10.1021/es300044h

Makarov, M.I., Haumaier, L., Zech, W., 2002. Nature of soil organic phosphorus: an assessment of peak assignments in the diester region of ${ }^{31}$ P NMR spectra. Soil Biol. Biochem. 34, 1467-1477. Manas, A., Biscans, B., Sperandio, M., 2011. Biologically induced phosphorus precipitation in aerobic granular sludge process. Water Res. 45, 3776-3786.

https://doi.org/10.1016/j.watres.2011.04.031

Marques, R., Santos, J., Nguyen, H., Carvalho, G., Noronha, J.P., Nielsen, P.H., Reis, M.A.M., Oehmen, A., 2017. Metabolism and ecological niche of Tetrasphaera and Ca. Accumulibacter in enhanced biological phosphorus removal. Water Res. 122, 159-171.

https://doi.org/10.1016/j.watres.2017.04.072

McIlroy, S.J., Kristiansen, R., Albertsen, M., Karst, S.M., Rossetti, S., Nielsen, J.L., Tandoi, V., Seviour, R.J., 2013. Metabolic model for the filamentous 'Candidatus Microthrix parvicella' based on genomic and metagenomic analyses. ISME J. 7, 1161-1172.

https://doi.org/10.1038/ismej.2013.6

McIlroy, S.J., Starnawska, A., Starnawski, P., Saunders, A.M., Nierychlo, M., Nielsen, P.H., Nielsen, J.L., 2016. Identification of active denitrifiers in full-scale nutrient removal wastewater treatment systems. Environ. Microbiol. 18, 50-64.

Menar, A.B., Jenkins, D., 1970. Fate of phosphorus in waste treatment processes: enhanced removal of phosphate by activated sludge. Environ. Sci. Technol. 4, 1115-1121.

https://doi.org/10.1021/es60047a005

Metcalf \& Eddy Inc., Abu-Orf, M., Bowden, G., Burton, F.L., Pfrang, W., Stensel, H.D., Tchobanoglous, G., Tsuchihashi, R., 2014. Wastewater engineering: treatment and resource recovery., Fifth Edit. ed. McGraw Hill Education.

Mielczarek, A.T., Thi, H., Nguyen, T., Nielsen, J.L., Nielsen, P.H., 2013. Population dynamics of bacteria involved in enhanced biological phosphorus removal in Danish wastewater treatment plants. Water Res. 47, 1529-1544. https://doi.org/10.1016/j.watres.2012.12.003

Mino, T., Kawakami, T., Matsuo, T., 1984. Location of phosphorus in activated sludge and function of intracellular polyphosphates in biological phosphorus removal process. Water Sci. Technol. 17, 93-106.

Nielsen, J.L., 2009. Protocol for fluorescence in situ hybridization (FISH) with rRNA-targeted oligonucleotides, in: FISH Handbook for Biological Wastewater Treatment. pp. 73-84.

Nielsen, J.L., Nielsen, P.H., 2002. Enumeration of acetate-consuming bacteria by microautoradiography under oxygen and nitrate respiring conditions in activated sludge. Water Res. $36,421-428$. 
Nielsen, P.H., Mcilroy, S.J., Albertsen, M., Nierychlo, M., 2019. Re-evaluating the microbiology of the enhanced biological phosphorus removal process. Curr. Opin. Biotechnol. 57, 111-118. https://doi.org/10.1016/j.copbio.2019.03.008

Nielsen, P.H., Roslev, P., Dueholm, T.E., Nielsen, J.L., 2002. Microthrix parvicella, a specialized lipid consumer in anaerobic-aerobic activated sludge plants. Water Sci. Technol. 46, 73-80. Nierychlo, M., McIlroy, S.J., Kucheryavskiy, S. V., Jiang, C., Ziegler, A.S., Kondrotaite, Z., Stokholm-Bjerregaard, M., Nielsen, P.H., 2020. Candidatus Amarolinea and Candidatus Microthrix Are Mainly Responsible for Filamentous Bulking in Municipal Danish Wastewater Treatment Plants. Front. Microbiol. https://doi.org/https://doi.org/10.3389/fmicb.2020.01214

Nierychlo, M., Thomsen, L., Petriglieri, F., Nielsen, P.H. Diversity of Candidatus Microthrix filamentous species in WWTPs and their role in sludge settling problems. Unpublished.

Oehmen, A., Lemos, P.C., Carvalho, G., Yuan, Z., Blackall, L.L., Reis, M.A.M., 2007. Advances in enhanced biological phosphorus removal: From micro to macro scale. Water Res. 41, 2271-2300. https://doi.org/10.1016/j.watres.2007.02.030

Op Den Kamp, J.A.F., Redai, I., van Deenen, L.L.M., 1969. Phospholipid Composition of Bacillus subtilis. J. Bacteriol. 99, 298-303.

Petriglieri, F., Singleton, C., Peces, M., Petersen, J.F., Nierychlo, M., Nielsen, P.H., 2020. "Candidatus Dechloromonas phosphatis" and "Candidatus Dechloromonas phosphovora", two novel polyphosphate accumulating organisms abundant in wastewater treatment systems. bioRxiv 2020.11.05.369777. https://doi.org/10.1101/2020.11.05.369777

Pinkart, H.C., White, D.C., 1997. Phospholipid Biosynthesis and Solvent Tolerance in Pseudomonas putida Strains. J. Bacteriol. 179, 4219-4226.

Qiu, G., Zuniga-montanez, R., Law, Y., Swa, S., 2019. Polyphosphate-accumulating organisms in full-scale tropical wastewater treatment plants use diverse carbon sources. Water Res. 149, 469510. https://doi.org/10.1016/j.watres.2018.11.011

Rasmussen, H., Bruus, J.H., Keiding, K., Nielsen, P.H., 1994. Obeservations on dewaterability and physical, chemical and microbiological changes in anaerobically stored activated sludge from a nutrient removal plant. Water Res. 28, 417-425.

Reitzel, K., 2005. Separation of aluminum bound phosphate from iron bound phosphate in freshwater sediments by a sequential extraction procedure, in: Phosphates in Sediments. pp. 109117.

Roske, I., Schonborn, C., 1994. Interactions between chemical and advanced biological phosphorus elimination. Water Res. 28, 1103-1109.

Schneider, C.A., Rasband, W.S., Eliceiri, K.W., 2012. NIH Image to ImageJ: 25 years of image analysis. Nat. Methods 9, 671-675. https://doi.org/10.1038/nmeth.2089

Schonborn, C., Bauer, H.-D., Roske, I., 2001. Stability of enhanced biological phosphorus removal and composition of polyphosphate granules. Water Res. 35, 3190-3196.

Shiba, N.C., Ntuli, F., 2017. Extraction and precipitation of phosphorus from sewage sludge. Waste Manag. 60, 191-200. https://doi.org/10.1016/j.wasman.2016.07.031

Staal, L.B., Petersen, A.B., Jørgensen, C.A., Gro, U., Halkjær, P., Reitzel, K., 2019. Extraction and quantification of polyphosphates in activated sludge from waste water treatment plants by ${ }^{31} \mathrm{P} N \mathrm{NR}$ spectroscopy. Water Res. 157, 346-355. https://doi.org/10.1016/j.watres.2019.03.065 
Stokholm-Bjerregaard, M., McIlroy, S.J., Nierychlo, M., Karst, S.M., Albertsen, M., Nielsen, P.H., 2017. A critical assessment of the microorganisms proposed to be important to enhanced biological phosphorus removal in full-scale wastewater treatment systems. Front. Microbiol. 8, 718. https://doi.org/10.3389/FMICB.2017.00718 Uhlmann, D., Roske, I., Hupfer, M., Ohms, G., 1990. A simple method to distinguish between polyphosphate and other phosphate fractions of activated sludge. Water Res. 24, 1355-1360. Urban, V., Block, J.C., Manem, J., 1993. Bioflocculation in activated sludge: an analytic approach. Water Res. 27, 829-838.

Van Veen, W.L., 1973. Bacteriology of activated sludge, in particular the filamentous bacteria. Antonie Van Leeuwenhoek 39, 189-205.

Vollertsen, J.E.S., Jahn, A., Nielsen, J.L., Hvitved-Jacobsen, T., Nielsen, P.H., 2001. Comparison of methods for determination of microbial biomass in wastewater. Water Res. 35, 1649-1658. Vuuren, D.P. Van, Bouwman, A.F., Beusen, A.H.W., 2010. Phosphorus demand for the $1970-$ 2100 period $\square$ : A scenario analysis of resource depletion. Glob. Environ. Chang. 20, 428-439. https://doi.org/10.1016/j.gloenvcha.2010.04.004

Wang, J., Liu, Q., Qi, R., Tandoi, V., Yang, M., 2014a. Sludge bulking impact on relevant bacterial populations in a full-scale municipal wastewater treatment plant. Process Biochem. 2258-2265. Wang, J., Qi, R., Liu, M., Li, Q., Bao, H., Li, Y., Wang, S., Tandoi, V., Yang, M., 2014b. The potential role of 'Candidatus Microthrix parvicella' in phosphorus removal during sludge bulking in two full-scale enhanced biological phosphorus removal plants. Water Sci. Technol. 70, 367-375. https://doi.org/10.2166/wst.2014.216 Wilfert, P., Dugulan, A.I., Goubitz, K., Korving, L., Witkamp, G.J., Van Loosdrecht, M.C.M., 2018. Vivianite as the main phosphate mineral in digested sewage sludge and its role for phosphate recovery. Water Res. 144, 312-321. https://doi.org/10.1016/j.watres.2018.07.020

Wilfert, P., Kumar, P.S., Korving, L., Witkamp, G.J., Van Loosdrecht, M.C.M., 2015. The Relevance of Phosphorus and Iron Chemistry to the Recovery of Phosphorus from Wastewater: A Review. Environ. Sci. Technol. 49, 9400-9414. https://doi.org/10.1021/acs.est.5b00150 Wilfert, P., Mandalidis, A., Dugulan, A.I., Goubitz, K., Korving, L., Temmink, H., 2016. Vivianite as an important iron phosphate precipitate in sewage treatment plants. Water Res. 104, 449-460. https://doi.org/10.1016/j.watres.2016.08.032

Xie, C., Zhao, J., Tang, J., Xu, J., Lin, X., Xu, X., 2011. The phosphorus fractions and alkaline phosphatase activities in sludge. Bioresour. Technol. 102, 2455-2461.

https://doi.org/https://doi.org/10.1016/j.biortech.2010.11.011

Yuan, Z., Pratt, S., Batstone, D.J., 2012. Phosphorus recovery from wastewater through microbial processes. Curr. Opin. Biotechnol. 23, 878-83.

Zhang, H., Fang, W., Wang, Y., Sheng, G., Xia, C., Zeng, R.J., Yu, H., 2013a. Species of phosphorus in the extracellular polymeric substances of EBPR sludge. Bioresour. Technol. 142, 714-718. https://doi.org/10.1016/j.biortech.2013.05.068

Zhang, H., Fang, W., Wang, Y., Sheng, G., Zeng, R.J., Li, W., Yu, H., 2013b. Phosphorus Removal in an Enhanced Biological Phosphorus Removal Process: Roles of Extracellular Polymeric Substances. Environ. Sci. Technol. 47, 11482-11489. https://doi.org/10.1021/es403227p 
Zhang, H., Sheng, G., Fang, W., Wang, Y., Fang, C., 2015. Calcium effect on the metabolic pathway of phosphorus accumulating organisms in enhanced biological phosphorus removal systems. Water Res. 84, 171-180. https://doi.org/10.1016/j.watres.2015.07.042

Ziegler, M., Lange, M., Dott, W., 1990. Isolation and morphological and cytological characterization of filamentous bacteria from bulking sludge. Water Res. 24, 1437-1451. 


\section{Tables}

Table 1. Chemical composition of the four different activated sludges measured by ICP-OES. Values are given in $\mathrm{mg} / \mathrm{gSS}$.

\begin{tabular}{|c|c|c|c|c|c|c|c|c|}
\hline WWTP & Total P & $\mathbf{N a}$ & $\mathbf{K}$ & Ca & Mg & Mn & $\mathbf{F e}$ & Al \\
\hline Aalborg West & $49.68 \pm 1.89$ & $74.63 \pm 25.63$ & $23.03 \pm 0.64$ & $53.83 \pm 1.51$ & $14.09 \pm 0.43$ & $0.15 \pm 0.00$ & $15.89 \pm 0.64$ & $3.40 \pm 0.33$ \\
\hline Ejby Mølle & $35.85 \pm 2.87$ & $49.53 \pm 18.12$ & $18.58 \pm 1.00$ & $62.35 \pm 8.35$ & $10.18 \pm 1.92$ & $0.32 \pm 0.12$ & $27.64 \pm 4.88$ & $3.16 \pm 0.11$ \\
\hline Lynetten & $37.10 \pm 1.74$ & $68.88 \pm 25.45$ & $18.00 \pm 1.39$ & $54.12 \pm 5.50$ & $13.44 \pm 1.55$ & $0.23 \pm 0.12$ & $25.75 \pm 4.65$ & $3.40 \pm 0.19$ \\
\hline Viby & $45.18 \pm 2.26$ & $50.38 \pm 22.75$ & $15.28 \pm 0.29$ & $54.96 \pm 1.36$ & $8.64 \pm 0.28$ & $0.41 \pm 0.02$ & $52.24 \pm 2.67$ & $4.30 \pm 0.43$ \\
\hline
\end{tabular}


Table 2. Summary of estimates of bacterial cell number and cell size in activated sludge.

\begin{tabular}{|c|c|c|c|c|c|c|c|}
\hline Sampling type & $\begin{array}{l}\text { SS } \\
(\mathrm{g} / \mathrm{L})\end{array}$ & $\begin{array}{l}\text { VSS } \\
(\mathrm{g} / \mathrm{L})\end{array}$ & $\begin{array}{l}\text { Cell number } \\
\text { (cells/L) }\end{array}$ & Cell number & $\begin{array}{l}\text { Method for cells } \\
\text { numbers }\end{array}$ & Size $\left(\mu \mathbf{m}^{3} /\right.$ cell $)$ & Reference \\
\hline Activated sludge & $8-11^{\mathrm{a}}$ & N/A & N/A & $5.00 \times 10^{11 \mathrm{~b}}$ & AO staining & $0.249 \pm 0.239^{\#}$ & Frølund et al., 1996 \\
\hline Activated sludge & $9-15^{\mathrm{a}}$ & $5-10$ & $1.53 \times 10^{12}$ & $8.00 \times 10^{11 \mathrm{~b}}$ & AO staining & N/A & $\begin{array}{l}\text { Rasmussen et al., } \\
1994\end{array}$ \\
\hline Activated sludge & N/A & N/A & $4.11 \times 10^{12}$ & $26.3 \times 10^{11 * c}$ & AO staining & N/A & Urbain et al., 1993 \\
\hline Activated sludge (primary aerobic zone) & N/A & N/A & $4.41 \times 10^{11}$ & N/A & AO staining & N/A & $\begin{array}{l}\text { Cloete and Steyn } \\
1988\end{array}$ \\
\hline Wastewater & N/A & N/A & $\approx 1.75 \times 10^{11}$ & N/A & AO staining & $0.285 \pm 0.042^{\#}$ & $\begin{array}{l}\text { Vollertsen et al., } \\
2001\end{array}$ \\
\hline $\begin{array}{l}\text { Activated sludge (aerobic tank - Aalborg West } \\
\text { WWTP) }\end{array}$ & N/A & N/A & $6.60 \times 10^{11}$ & $2.00 \times 10^{11 * c}$ & DAPI staining & N/A & $\begin{array}{l}\text { Nielsen \& Nielsen } \\
2002\end{array}$ \\
\hline Activated sludge (aerobic tank - Aabybro WWTP) & N/A & N/A & $1.43 \times 10^{12}$ & $4.40 \times 10^{11 * c}$ & DAPI staining & N/A & $\begin{array}{l}\text { Nielsen \& Nielsen } \\
2002\end{array}$ \\
\hline $\begin{array}{l}\text { Activated sludge (aerobic tank -Aalborg East } \\
\text { WWTP) }\end{array}$ & N/A & N/A & $2.77 \times 10^{12}$ & $7.50 \times 10^{11 * c}$ & DAPI staining & N/A & $\begin{array}{l}\text { Nielsen \& Nielsen } \\
2002\end{array}$ \\
\hline Activated sludge (aerobic tank -Aarestrup WWTP) & N/A & N/A & $5.80 \times 10^{11}$ & $5.50 \times 10^{11 * c}$ & DAPI staining & N/A & $\begin{array}{l}\text { Nielsen \& Nielsen } \\
2002\end{array}$ \\
\hline Activated sludge & N/A & N/A & $2.24 \times 10^{12}$ & N/A & Flow cytometry & N/A & Ma et al., 2013 \\
\hline Activated sludge & N/A & 3.05 & $3.30 \times 10^{12}$ & $1.10 \times 10^{12 \mathrm{c}}$ & Flow cytometry & N/A & Foladori et al., 2010 \\
\hline $\begin{array}{l}\text { Activated sludge (aerobic tank - Aalborg West } \\
\text { WWTP) }\end{array}$ & 4.00 & 3.00 & $\begin{array}{l}1.81 \pm 0.34 \\
\times 10^{11}\end{array}$ & $6.46 \times 10^{11 \mathrm{c}}$ & & & \\
\hline Activated sludge (aerobic tank - Ejby-Mølle WWTP) & 3.40 & 2.80 & $\begin{array}{l}1.06 \pm 0.34 \\
\times 10^{11}\end{array}$ & $3.78 \times 10^{11 \mathrm{c}}$ & DAPI staining & $0.363 \pm 0.240^{\#}$ & This study \\
\hline Activated sludge (aerobic tank - Lynetten WWTP) & 3.90 & 3.10 & $\begin{array}{l}1.82 \pm 0.62 \\
\times 10^{11}\end{array}$ & $5.87 \times 10^{11 \mathrm{c}}$ & & $0.608 \pm 0.245^{\infty}$ & \\
\hline Activated sludge (aerobic tank - Viby WWTP) & 4.20 & 2.8 & $\begin{array}{l}1.34 \pm 0.46 \\
\times 10^{11}\end{array}$ & $4.78 \times 10^{11 \mathrm{c}}$ & & & \\
\hline
\end{tabular}

*=Calculated based on the published values

\#=rod-shaped and spheroidal cells

a $=$ filaments

$\mathrm{a}=$ unit: TS g/L; b= unit: Cells/gVS; $c=$ unit: Cell/gVSS 
Table 3. Total P, total poly-P, and anaerobic P-release in activated sludge measured by independent methods.

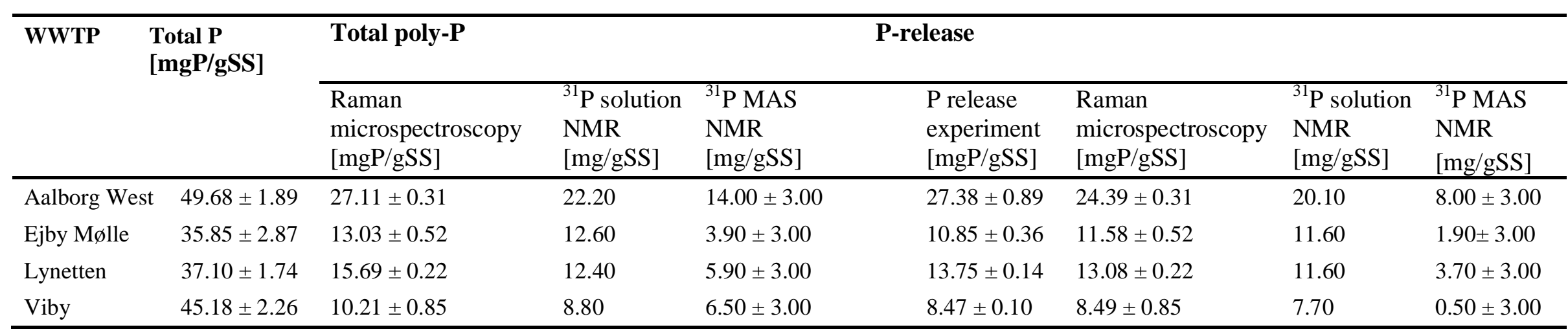

Table 4. Summary of average poly-P per cell and total poly-P in activated sludge measured by Raman microspectroscopy. Total poly-P was obtained by multiplying the average poly-P per cell by total number of cells.

\begin{tabular}{ccccc}
\hline \multirow{2}{*}{ WWTP } & \multicolumn{2}{c}{ Aerobic phase $(\mathbf{0}$ h) } & \multicolumn{2}{c}{ Anaerobic phase $(\mathbf{3}$ h) } \\
\cline { 2 - 5 } & $\begin{array}{c}\text { Average poly-P per } \\
\text { cell }\left(* 10^{-14} \mathrm{gP} \mathrm{cell}{ }^{-1}\right)\end{array}$ & $\begin{array}{c}\text { Total poly-P } \\
{[\mathrm{mgP} / \mathrm{gSS}]}\end{array}$ & $\begin{array}{c}\text { Average poly-P per cell } \\
\left(* 10^{-14} \mathrm{gP} \text { cell }{ }^{-1}\right)\end{array}$ & $\begin{array}{c}\text { Total poly-P } \\
{[\mathrm{mgP} / \mathrm{gSS}]}\end{array}$ \\
\hline Aalborg West & $5.38 \pm 0.11$ & $27.11 \pm 0.31$ & $0.54 \pm 0.61$ & $2.72 \pm 0.31$ \\
Ejby-Mølle & $4.31 \pm 0.90$ & $13.03 \pm 0.52$ & $0,48 \pm 0.11$ & $1.45 \pm 0.52$ \\
Lynetten & $2.86 \pm 0.21$ & $15.69 \pm 0.22$ & $0.47 \pm 0.30$ & $2.60 \pm 0.22$ \\
Viby & $2.85 \pm 0.55$ & $10.21 \pm 0.85$ & $0.33 \pm 0.82$ & $1.72 \pm 0.85$ \\
\hline
\end{tabular}


Table 5. Summary of relative abundances (\%) of PAOs in activated sludge of the 4 WWTP measured by amplicon sequencing and q-FISH.

\begin{tabular}{|c|c|c|c|c|c|c|c|c|c|c|}
\hline \multirow[t]{2}{*}{ WWTP } & \multicolumn{2}{|c|}{ Ca. Accumulibacter } & \multicolumn{2}{|c|}{ Tetrasphaera } & \multicolumn{2}{|c|}{ Dechloromonas } & \multicolumn{2}{|c|}{ Ca. Microthrix } & \multicolumn{2}{|c|}{$\begin{array}{c}\text { Total conventional } \\
\text { PAOs }\end{array}$} \\
\hline & Sequencing & qFISH & Sequencing & $\mathrm{qFISH}$ & Sequencing & qFISH & Sequencing & qFISH & Sequencing & $\mathrm{qFISH}$ \\
\hline Aalborg West & 0.9 & $3.4 \pm 1.1$ & 6.7 & $6.4 \pm 1.8$ & 5.0 & $2.6 \pm 1.1$ & 3.7 & $7.3 \pm 2.6$ & 12.6 & 12.4 \\
\hline Ejby-Mølle & 0.8 & $5.2 \pm 2.9$ & 4.7 & $4.0 \pm 1.2$ & 1.5 & $1.7 \pm 0.9$ & 1.1 & $1.5 \pm 1.1$ & 7 & 10.9 \\
\hline Lynetten & 0.4 & $2.6 \pm 1.2$ & 3.6 & $2.0 \pm 0.8$ & 3.6 & $5.7 \pm 1.9$ & 3.0 & $4.0 \pm 2.3$ & 7.6 & 10.3 \\
\hline Viby & 0.3 & $1.0 \pm 0.5$ & 3.1 & $1.9 \pm 0.6$ & 2.8 & $2.9 \pm 1.1$ & 4.5 & $7.2 \pm 3.8$ & 6.2 & 5.8 \\
\hline
\end{tabular}


Table 6. Summary of total $\mathrm{P}, \mathrm{P}$ content in DNA, and $\mathrm{P}$ content in lipids in pure cultures compared to activated sludge samples.

\begin{tabular}{|c|c|c|c|c|c|}
\hline Sample type & $\begin{array}{l}\text { Total P } \\
{[\mathrm{mgP} / \mathrm{gSS}]}\end{array}$ & $\begin{array}{l}\text { P-DNA } \\
{[\mathrm{mgP} / \mathrm{gSS}]}\end{array}$ & $\begin{array}{l}\text { P-Lipid } \\
{[\mathrm{mgP} / \mathrm{gSS}]}\end{array}$ & Method for extraction and quantification & Reference \\
\hline Bacillus subtilis & $15.97-18.38$ & $0.35-0.39$ & $8.44-9.32$ & $\begin{array}{l}\text { Extraction with } 0.1 \mathrm{M} \mathrm{NaOH}(16 \mathrm{~h}) ; 31 \mathrm{P} \mathrm{NMR} \\
\text { spectroscopy }\end{array}$ & Marakov et al., 2002 \\
\hline Bacillus subtilis & N/A & N/A & $0.51-0.59$ & $\begin{array}{l}\text { Extraction Chloroform:Methanol:Water (1:2:0.8 } \\
\text { v/v); Thin Layer Chromatography }\end{array}$ & Op den Kan et al., 1969 \\
\hline Pseudomonas putida & $13.70-15.55$ & $1.70-2.78$ & $0.26-1.21$ & $\begin{array}{l}\text { Extraction with } 0.1 \mathrm{M} \mathrm{NaOH}(16 \mathrm{~h}) ; 31 \mathrm{P} \text { NMR } \\
\text { spectroscopy }\end{array}$ & Marakov et al., 2002 \\
\hline Pseudomonas putida & N/A & N/A & $2.39-2.61$ & $\begin{array}{l}\text { Extraction Chloroform:Methanol:Water (1:2:0.8 } \\
\text { v/v); High-Pressure Liquid Chromatography }\end{array}$ & Pinkart and White 1997 \\
\hline Chromatiaceae spp & N/A & N/A & $1.18-4.29 \mathrm{a}$ & $\begin{array}{l}\text { Extraction with Methanol:Chloroform (2.1:0.8 } \\
\text { v/v); Thin Layer Chromatography }\end{array}$ & Imhoff et al., 1982 \\
\hline Rhodospiriilaceae spp & N/A & N/A & $1.42-5.75 a$ & $\begin{array}{l}\text { Extraction with Methanol:Chloroform (2.1:0.8 } \\
\text { v/v); Thin Layer Chromatography }\end{array}$ & Imhoff et al., 1982 \\
\hline Methylococcus capsulatus & N/A & N/A & 3.28 & $\begin{array}{l}\text { Extraction Chloroform:Methanol:Water (2:1:0.1 } \\
\text { v/v); Thin Layer Chromatography }\end{array}$ & Makula 1978 \\
\hline Methylosinus trichosporium & N/A & N/A & 3.59 & $\begin{array}{l}\text { Extraction Chloroform:Methanol:Water (2:1:0.1 } \\
\text { v/v); Thin Layer Chromatography }\end{array}$ & Makula 1978 \\
\hline \multicolumn{6}{|l|}{$\begin{array}{l}\text { Activated sludge (Aerobic } \\
\text { tank) }\end{array}$} \\
\hline Aalborg West WWTP) & $49.7 \pm 1.9$ & $1.1-1.3$ & $0.5-0.6$ & $\begin{array}{l}\text { Extraction } 0.05 \mathrm{M} \text { EDTA }(1 \mathrm{~h})+0.25 \mathrm{M} \mathrm{NaOH} \\
(16 \mathrm{~h}) ; 31 \mathrm{P} \text { NMR spectroscopy }\end{array}$ & This study \\
\hline Ejby-Mølle WWTP) & $35.8 \pm 2.9$ & $0.9-1.2$ & $0.4-0.5$ & $\begin{array}{l}\text { Extraction 0.05 M EDTA }(1 \mathrm{~h})+0.25 \mathrm{M} \mathrm{NaOH} \\
(16 \mathrm{~h}) ; 31 \mathrm{P} \text { NMR spectroscopy }\end{array}$ & This study \\
\hline Lynetten WWTP) & $37.1 \pm 1.7$ & $0.9-1.2$ & $0.3-0.6$ & $\begin{array}{l}\text { Extraction } 0.05 \mathrm{M} \text { EDTA }(1 \mathrm{~h})+0.25 \mathrm{M} \mathrm{NaOH} \\
(16 \mathrm{~h}) ; 31 \mathrm{P} \text { NMR spectroscopy }\end{array}$ & This study \\
\hline Viby WWTP) & $45.2 \pm 2.3$ & $1.1-1.4$ & $0.1-0.5$ & $\begin{array}{l}\text { Extraction } 0.05 \mathrm{M} \text { EDTA }(1 \mathrm{~h})+0.25 \mathrm{M} \mathrm{NaOH} \\
\text { (16h); 31P NMR spectroscopy }\end{array}$ & This study \\
\hline
\end{tabular}




\begin{tabular}{|c|c|c|c|c|c|c|c|c|}
\hline \multirow[t]{2}{*}{ WWTP } & \multicolumn{4}{|c|}{ Poly-P in aerobic phase $(0 \mathrm{~h})\left(* 10^{-14} \mathrm{gP}\right.$ cell $\left.^{-1}\right)$} & \multicolumn{4}{|c|}{ Poly-P in anaerobic phase $(3 \mathrm{~h})\left(* 10^{-14} \mathrm{gP}\right.$ cell $\left.^{-1}\right)$} \\
\hline & Ca. Accumulibacter & Tetrasphaera & Dechloromonas & Ca. Microthrix & Ca. Accumulibacter & Tetrasphaera & Dechloromonas & Ca. Microthrix \\
\hline Aalborg West & $15.7 \pm 0.51$ & $1.68 \pm 0.15$ & $6.40 \pm 0.23$ & $1.75 \pm 0.11$ & $1.13 \pm 0.71$ & $0.49 \pm 0.42$ & $0.71 \pm 0.36$ & $1.44 \pm 0.41$ \\
\hline Ejby Mølle & $14.7 \pm 0.72$ & $1.79 \pm 0.62$ & $6.95 \pm 0.44$ & $2.22 \pm 0.71$ & $1.10 \pm 0.14$ & $0.83 \pm 0.31$ & $0.86 \pm 0.33$ & $1.86 \pm 0.62$ \\
\hline Lynetten & $15.7 \pm 0.55$ & $1.84 \pm 0.41$ & $6.52 \pm 0.18$ & $1.51 \pm 0.22$ & $1.01 \pm 0.32$ & $0.47 \pm 0.72$ & $0.65 \pm 0.25$ & $1.26 \pm 0.31$ \\
\hline Viby & $10.7 \pm 0.13$ & $1.07 \pm 0.71$ & $6.21 \pm 0.22$ & $1.12 \pm 0.52$ & $1.46 \pm 0.81$ & $0.83 \pm 0.61$ & $0.73 \pm 0.36$ & $1.00 \pm 0.11$ \\
\hline
\end{tabular}

Table 7. Summary of the content of poly-P in probe-defined PAOs in activated sludge. 